\title{
LEGAL ENTITIES AS TRANSFERABLE BUNDLES OF CONTRACTS
}

\author{
Kenneth Ayotte* \\ Henry Hansmann**
}

The large, modern business corporation is frequently organized as a complex cluster of hundreds of corporate subsidiaries under the common control of a single corporate parent. Our Article provides new theory and supportive evidence to help explain this structure. We focus, in particular, on the advantages of subsidiary entities in providing the option to transfer some or all of the firm's contractual rights and obligations in the future. The theory not only sheds light on corporate subsidiaries but also illuminates a basic function of all types of legal entities, from partnerships to nonprofit corporations.

We show that when, as is common, some of a firm's key assets are contractual, both the firm's owner(s) and its contractual counterparties are exposed to the risk of opportunism. relating to the assignment of the contracts. The owner faces opportunistic holdup by counterparties if counterparty consent is required to assign contracts in a sale of the entire firm. The firm's counterparties, in turn, are exposed to opportunistic assignment if the owner can freely assign contracts without consent. This bilateral opportunism problem can be mitigated through bundled assignability: the owner is permitted to assign her contracts freely but only as a bundle. The components of the bundle of contracts (which constitute much of the firm itself) provide assurance of performance to counterparties. And free transferability, in turn, gives the owner liquidity without risk of holdup. Most importantly-and least appreciated in the literature and the case law-bundled assignability increases the owner's incentive to make valuable investments in the firm.

* Professor of Law, Northwestern University School of Law.

** Oscar M. Ruebhausen Professor of Law, Yale Law School.

For helpful comments on earlier versions of this Article we would like to thank participants in the American Law and Economics Association annual meeting in San Diego, the Law and Finance Seminar at the University of Oxford, the Corporate Separateness Conference at Vanderbilt University, the Law and Economics Seminars at Boston University, Harvard University, the National Bureau of Economic Research, Northwestern University, the University of Siena, and the University of Western Ontario, and the Yale Law School faculty workshop. For individual comments and assistance, we would particularly like to thank Barry Adler, Margaret Blair, Patrick Bolton, Albert Choi, Jens Dammann, William Eskridge, Oliver Hart, Marshall Heubner, Edward Iacobucci, Louis Kaplow, Paul Kingsley, Ruben Kraiem, Shmuel Leshem, Bentley MacLeod, Charles Nathan, Megan O'Flynn, Eric Rasmussen, Eric Schanze, Alan Schwartz, Urs Schweizer, Simone Sepe, Henry Smith, and Richard Squire. We are grateful to Robert Borek, Quinn Curtis, Eric Fish, Seunghee Ham, Dylan Hanson, Jonathan Meltzer, Jesse Payne-Johnson, Rae Shih, and Joanne Williams for excellent research assistance. Professor Ayotte thanks the Ewing and Marion Kauffman Foundation for generous research support. 
We explain why legal entities provide the simplest, most reliable means of creating bundled assignability. Further, we support our analysis with the first empirical study of assignment clauses in commercial contracts. Firms, we show, commonly provide for bundled assignability in their contracts, and they use legal entities to define the boundaries of transferable bundles. This suggests that our theoretical model accurately captures the motivations of contracting parties in practice.

\section{TABLE OF CONTENTS}

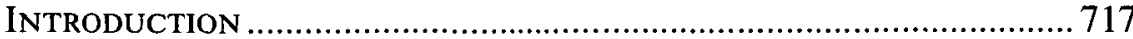

I. Current Theories of Legal Entities.................................718

A. The Economic Theory of the Firm: Property Rights ......... 719

B. The Law and Economics Perspective: Creditor Monitoring 720

II. A New Theory: BundLEd Assignability .......................... 722

A. The Law of Bundled Assignability ............................... 723

B. A Sketch of Our Theory ................................................ 725

III. A NumericAl EXAMPLE OF THE THEORY ............................. 728

A. Investments in Complementarities................................. 730

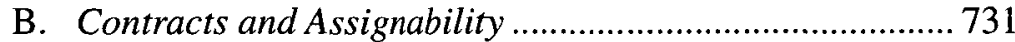

C. Credit Risk ................................................................ 732

D. Investment with Bundled Assignability............................ 732

E. Investment with Individual Assignability......................... 733

F. Comparing Individual and Bundled Assignability ........... 735

IV. Consequences of Changing the Assumptions.................735

A. Bundling Contracts with Assets Owned Outright.............. 736

B. Other Sources of Complementarities................................. 736

C. Other Sources of Inefficient Assignment............................ 736

D. Renegotiation in the Shadow of Assignment.....................737

E. Residual Liability ............................................................ 737

F. The Parent Company Has Other Assets and Liabilities .... 740

G. The Costs of Nonassignability...................................... 742

V. ACHIEVING Bundled Assigna BILITY WITH aND WithouT LEGAL ENTITIES .......................................................... 742

VI. EMPIRICAL EVIDENCE OF BUNDLED AsSignABILITY ..............745

VII. FURTHER IMPLICATIONS .................................................. 747

A. Bankruptcy Law and Individual Assignability ................. 747

B. Licenses for Intellectual Property ................................ 749

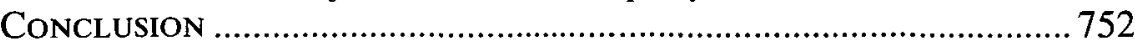

APPEndix A: Robustness CHECKS............................................ 754

1. Bundling Contracts to Assets .............................................. 754

2. Other Sources of Complementarity .................................... 754

3. Other Sources of Inefficient Assignment ...............................755

4. Renegotiation in the Shadow of Assignment ...................... 755

APPENDIX B: TABLES ................................................................ 756 
APPENDIX C: EXAMPLE OF EXPLICIT

Bundled-Assignability Clause.

\section{INTRODUCTION}

Despite all of the ink that has been spilled on the subject over the last two centuries, we still lack a full understanding of the many roles played by legal entities. To be sure, the basic structure and benefits of the most conspicuous type of legal entity-the publicly traded business corporation-are generally familiar. ${ }^{1}$ Less familiar, however, are corporate subsidiaries. Today, each of the largest 100 companies in the United States has, on average, about 250 distinct subsidiaries that are large enough to be reported in the firm's securities filings and presumably many more that are smaller. ${ }^{2}$ Most of these subsidiaries are wholly owned and consequently controlled by the parent company. Why do firms routinely adopt this structure, rather than managing their various activities as unincorporated divisions within the parent firm's corporate shell? What is the purpose of these subsidiary entities?

This question has been largely neglected in both the legal and the economics literature. An answer is important, however, for both law and practice. Courts and regulators must often decide whether to respect the corporate boundaries between commonly owned subsidiaries for purposes of accounting, veil piercing, taxation, and regulation. Bankruptcy courts have the power to "substantively consolidate" corporate groups, merging both the assets and the liabilities of a parent corporation's subsidiaries as if they were simply managerial divisions within a single corporate shell. If wholly owned subsidiaries are typically formed just for opportunistic reasons, such as misleading creditors or avoiding taxation or regulation, there may be a strong case for refusing to treat them as separate entities. If, conversely, subsidiaries commonly serve important economic functions, then the failure to respect the independent character of those subsidiaries when taxing or regulating them, or when sorting out creditors' claims in bankruptcy, comes at a price that should be taken into account.

We explore in this Article what we believe to be one important reasonthough clearly not the only reason-for organizing a set of activities as a distinct legal entity, even when that entity is wholly owned by another entity. Our explanation not only throws light on the role served by corporate subsidiaries but also illuminates the functions served by legal entities more generally. Our theory focuses on the great utility of legal entities in facilitating transferability, particularly when a firm's value depends greatly on its contractual rights. Legal entities provide a low-cost means of assembling complementary contracts into discrete bundles that can be freely transferred

1. See, e.g., John Armour et al., What Is Corporate Law?, in The Anatomy of CoRPORATE LAW 5-16 (Reinier Kraakman et al. eds., 2d ed. 2009) (describing the basic features of the business corporation and their respective functions).

2. See Richard Squire, Strategic Liability in the Corporate Group, 78 U. CHI. L. REv. 605,606 n.1 (2011). 
to a new owner, but only if the contracts are transferred together as a bundle. We refer to this feature as "bundled assignability."

Our theory explains why bundled assignability can be an efficient economic configuration. Bundled assignability constrains opportunism on the part of both the business's owner(s) and its contractual counterparties-its suppliers, employees, and customers - that can arise when transferability is at issue. With these opportunism problems minimized, owners have a greater incentive to make investments that add complementary value to the bundle.

We also explain why legal entities are useful tools in creating bundled assignability, and we present empirical evidence supporting our claim. In particular, we find that bundled assignability is a common feature of commercial contracts in practice, and legal entities are the predominant means of achieving it. To our knowledge, we are the first to provide theory and supportive empirical evidence on assignment terms in commercial contracts. Our theory and evidence also allow us to offer perspective on bankruptcy doctrine governing the transferability of contractual rights and obligations and to understand some of the current features of that doctrine.

We proceed as follows: Part I discusses briefly the current legal and economic theories of legal entities that are closest to the theory we propose here and that this Article builds upon. Part II explores the concept of bundled assignability, discussing first the ways in which bundled assignability is facilitated by current legal doctrine through the relationship between contract assignability and legal entities, followed by an intuitive sketch of our own theory of the economic efficiencies offered by bundled assignability. Part III, the heart of this Article, illustrates our theory with a numerical example. Part IV shows that the central elements of the bundled assignability theory continue to hold under a variety of plausible changes in the example's background assumptions. Part $V$ explores the value of legal entities in establishing bundled assignability. Part VI presents empirical evidence on the prevalence of bundled assignability in commercial contracts, and Part VII discusses further implications concerning bankruptcy doctrine and intellectual property rights.

\section{Current Theories of Legal Entities}

To set the stage for our analysis, it's helpful to take a brief look at existing theories of the functions served by legal entities, particularly entities with a single owner, such as corporate subsidiaries. We set aside entitiesand particularly subsidiaries-that are created principally to segregate assets and activities into distinct (and usually somewhat arbitrary) pools for ease of compliance with taxation or regulation. For example, firms operating in multiple jurisdictions may choose to subincorporate their operations in each jurisdiction to aid them in complying with-or taking advantage ofdifferences in the tax regimes across those jurisdictions. And a company with a captive insurance business will generally want to subincorporate that business for the sake of segregating, from the firm's other assets, the capital 
that regulators require it to hold as a reserve to back its insurance policies. We are interested here, instead, in the more basic economic functions served by legal entities in facilitating coordination of activities among the principal participants in an enterprise, namely its owners and the persons with whom the enterprise has contractual relationships, such as its employees, suppliers, and customers. That is, we are concerned with the utility of segregating activities into distinct legal entities even in the absence of taxation and regulation.

\section{A. The Economic Theory of the Firm: Property Rights}

At least since Ronald Coase's foundational 1937 article, ${ }^{3}$ economists have sought to develop a "theory of the firm" to explain the scope and structure of business organizations. These theories, including the currently dominant "property rights theory of the firm," focus on potential efficiencies or inefficiencies that arise from having assets held under common control. ${ }^{4}$ These theories are theories "of the firm" in the sense of the firm being the (ultimate) common owner of assets. These theories have difficulty, however, in explaining legal entities in general and subsidiaries in particular.

The basic logic of these theories is already familiar to many lawyers and legal scholars. We review it here briefly to clarify the ways in which our own theory both builds upon, and differs from, that logic.

Suppose that there are two assets (call them Asset 1 and Asset 2) that initially are owned by two different persons (call them, respectively, Able and Baker). Assets 1 and 2 must be used in combination to produce a product. (The assets here could be anything from individual machines to whole businesses.) The question is whether Assets 1 and 2 should remain in separate ownership with their joint use coordinated by means of an arms-length agreement between Able and Baker, or whether, alternatively, either Able or Baker should purchase the other's asset and coordinate the use of the assets by direct exercise of the rights of ownership.

Suppose that, for productive efficiency, Able must specialize Asset 1, at a cost to her, in a fashion that will make it usable only with Asset $2 .{ }^{5}$ Then there is an incentive for Able to own the two assets-that is, for Able to buy Asset 2 from Baker before Asset 1 is specialized. For if they are kept in separate ownership, then after Able has borne the cost of specializing Asset 1, Baker has both the incentive and the opportunity to "hold up" Able. In particular, Baker can threaten to withdraw Asset 2 from production unless Able gives him further compensation, thus capturing some of the value that Able added with the specialization investment. It follows that Able, anticipating such opportunism, will have less incentive to invest in specializing Asset 1

3. R.H. Coase, The Nature of the Firm, 4 Economica 386 (1937).

4. See, e.g., Sanford J. Grossman \& Oliver D. Hart, The Costs and Benefits of Ownership: A Theory of Vertical and Lateral Integration, 94 J. PoL. ECON. 691 (1986).

5. It must further be assumed here that the two firms cannot write, in advance, an enforceable contract that specifies both the investment to be made by Able and all the terms under which Able and Baker will interact in the future. 
in the first place. If, on the other hand, Able purchases Asset 2 from Baker before specializing Asset 1, there will be no occasion for opportunistic holdup by Baker. Able will receive all the returns from specialization, and thus will have the appropriate incentive to invest in it. Economic integration, through ownership of both assets by Able, will therefore be the efficient arrangement if Able is the only party who makes a specialization investment. ${ }^{6}$

The downside to Able owning both assets, of course, is that Baker would then have less incentive to make similar investments that specialize Asset 2 to Asset 1, because he would then experience a holdup problem at the hands of Able. If Baker's specialization investment is relatively more valuable than Able's investment, then economic integration under Baker's ownership is likely to be more efficient.

The optimal ownership structure, then, will depend on the relative importance of the potential investments Able and Baker might make and the value of these investments inside and outside the relationship. If Able's investment in Asset 1 is valuable without Asset 2, and Baker's investment in Asset 2 is valuable without Asset 1, then neither party is in a position to hold up the other. When assets are less complementary in this way, it is more likely that the efficient ownership structure is nonintegration: Able should own Asset 1 and Baker should own Asset 2, hence constituting two separate firms that coordinate their production activities by contracting.

Theories of this sort clearly have some power in explaining whether two firms should integrate into one firm or remain separately owned. They have nothing to say, however, about why an entrepreneur would incorporate her business or why a corporation would create wholly owned subsidiary corporations. Indeed, for the purposes of the property rights theory of the firm, there is no difference between, on the one hand, a single corporation with its various businesses operated as divisions and, on the other hand, the same businesses operated as separately incorporated but wholly owned subsidiaries of the parent. In either case, the parent corporation controls all of the assets, so these configurations are equivalent.

Like the property rights theory, our theory also relies on the importance of specialization investments and the potential for holdup problems as a driver of organizational structure. But our theory provides an explanation for the legal structure of firms that the property rights theory does not.

\section{B. The Law and Economics Perspective: Creditor Monitoring}

The legal (or law and economics) literature has come closer to explaining the legal structure of firms, offering a "creditor-monitoring" theory of subsidiaries. ${ }^{7}$ Firms routinely obtain credit from many of their contractual

6. Seminal work on such "transaction-specific investments" includes OLIVER E. WILLiamson, The ECONOMic Institutions of CAPITALism (1985) (drawing together material from earlier books and articles), and Benjamin Klein et al., Vertical Integration, Appropriable Rents, and the Competitive Contracting Process, 21 J.L. \& Econ. 297 (1978).

7. This theory was offered in Richard A. Posner, The Rights of Creditors of Affiliated Corporations, 43 U. CHI. L. REv. 499, 507-09, 516-17 (1976), and was developed further in 
counterparties. Those counterparties include not just financial institutions such as banks, but also suppliers who provide goods on credit, employees who are paid after rather than before they work, and customers who make payment before receiving delivery. To determine the terms on which they will extend credit to the firm, these persons must assess both the possibility that the business will fail and the likely value of the assets that will remain to pay creditors if it does.

Take for example a creditor who supplies cars to a car rental business that is wholly owned by a larger travel agency that also owns a chain of hotels. That creditor will be in a better position to assess the financial soundness of the car rental business than that of the hotel chain. A creditor that supplies laundry services to hotel chains, conversely, will be better able to assess the creditworthiness of the hotel chain. If both the hotel chain and the car rental business are part of the same legal entity, then both creditors are exposed to risks they cannot easily evaluate. If, in contrast, the car rental business and the hotel chain are organized as separate subsidiaries of the parent, each business-and hence the creditor of each business-will be largely insulated from the vicissitudes of the other business. Each creditor will therefore incur less risk and monitoring costs than if there were just a single entity, and these savings will likely be passed on, at least in part, to the travel agency and the laundry service in the form of lower borrowing costs.

In short, corporate subsidiaries are a way of partitioning a firm's assets into distinct pools for the sake of pledging those assets to distinct groups of creditors. ${ }^{8}$ In other words, the subsidiaries are playing a role much like that performed by security interests.

But facilitating creditor monitoring through asset partitioning, though evidently important, does not seem adequate in itself to provide a complete explanation of the proliferation of subsidiary companies that we observe. In many cases, subsidiaries in a corporate group house closely related business lines that are substantially interconnected. Public firms, moreover, typically do not provide separate accounts for each of their subsidiaries to investors; they provide only a single, consolidated account of their assets and liabilities. The creditor to one of the subsidiaries in a corporate group of this type might find it difficult to establish which assets will back her claim in the

Henry Hansmann \& Reinier Kraakman, The Essential Role of Organizational Law, 110 YALE L.J. 387, 399-401 (2000), and Henry Hansmann et al., Law and the Rise of the Firm, 119 HARV. L. REV. 1333, 1344-45 (2006).

8. This partitioning takes two forms. First, limited liability protects the assets of the parent from the subsidiary's creditors. Second, the "entity shielding" provided by the corporate form protects the assets of the subsidiary from the creditors of the parent, assuring that those assets will be available in their entirety to satisfy the claims of the subsidiary's own creditors. See Hansmann \& Kraakman, supra note 7, at 393-98; Hansmann et al., supra note 7 , at $1337-43$. 
event of a default. The ambiguity of entity boundaries, therefore, may in fact raise creditor-monitoring costs in large corporate groups, not lower them. ${ }^{9}$

\section{A New Theory: Bundled Assignability}

We offer here a new theory, "bundled assignability," to explain the creation of subsidiary corporations and indeed legal entities in general. ${ }^{10}$ This theory complements the creditor-monitoring theory in the sense that both theories arguably predict roughly similar patterns of subsidiary companies. But the two theories differ in significant respects. Most importantly, while the creditor-monitoring theory focuses primarily on the costs of evaluation, the bundled-assignability theory focuses on the utility of legal entities in providing liquidity to the owners of a business segment by facilitating free transferability of that segment to a new owner. Thus, our theory, in contrast to other theories, can help explain why corporations often choose to house a business segment-whether acquired from another firm or developed internally-as a separate subsidiary entity when the corporation anticipates selling that segment in the future. ${ }^{11}$ The bundled-assignability theory is most easily understood if we first examine the relevant law that the theory seeks to illuminate.

9. See Squire, supra note 2, at 616-17. Another strong indication that the creditormonitoring theory is insufficient is the common practice of cross-guarantees among corporate subsidiaries. Subsidiaries often guarantee the debt of the parent firm or of other subsidiaries that are above, below, or parallel to them in the chains of subsidiaries that descend from the parent. See id. at 614-15.

10. Another theory argues that subsidiary corporations can-and perhaps must-be used to tailor both capital structures and managerial incentives to particular business segments within a larger firm. See Edward M. Iacobucci \& George G. Triantis, Economic and Legal Boundaries of Firms, 93 VA. L. REv. 515 (2007). And yet another theory, related to the creditor-monitoring theory discussed above, is offered by Margaret Blair, who points to the importance of the corporate form to increase the stability of enterprise by limiting the rights of a firm's owners to withdraw their share of capital from the firm. See Margaret M. Blair, Locking in Capital: What Corporate Law Achieved for Business Organizers in the Nineteenth Century, 51 UCLA L. REV. 387, 392-93 (2003). The latter theory, however, which focuses principally on relations among the owners of an entity rather than the relationship between the entity and its contractual counterparties, offers little help in understanding the role of corporate subsidiaries and other entities that have a single owner.

11. The popular video rental company Netflix, discussed infra in Section II.B, serves as fan example. In September 2011, Netflix made a very public announcement of a plan to separate its DVD business (renamed "Qwikster") from its streaming video business-a plan subsequently abandoned owing to consumer protests. Analysts speculated that Netflix planned to sell Qwikster, and placing Qwikster into a separate, wholly-owned subsidiary was a way to facilitate this eventual sale. See Matthew Shaer, Did Netflix Create Qwikster Just to Sell It?, Christian Sci. MONITOR, Sept. 21, 2011, http://www.csmonitor.com/Innovation/Horizons/ 201 1/0921/Did-Netflix-create-Qwikster-just-to-sell-it. 


\section{A. The Law of Bundled Assignability}

Contract law determines when rights and obligations under a contract may be transferred (or, as we say somewhat loosely, assigned ${ }^{12}$ ) to a third party. Both permission from the counterparty, and the subject and circumstances of the contract, inform this determination. For example, the rights of a promisee under a simple contract for payment of a definite sum of money are, as a default rule of contract law, generally presumed to be assignable. ${ }^{13}$ In contrast, the rights of an employer to receive labor services from an employee are generally presumed to be nonassignable. ${ }^{14}$

Whatever the default rule, the assignability of a contract can generally be altered by a specific provision in the contract itself. ${ }^{15}$ For example, although leaseholds are presumed to be assignable by the tenant, ${ }^{16}$ it is extremely common for assignability to be curtailed by a clause in the lease prohibiting the tenant from assigning the lease without the consent of the landlord. ${ }^{17}$

In contrast, if a business corporation (or other legal entity ${ }^{18}$ ) is a party to a contract, a transfer of some or even all of the ownership shares in the cor-

12. The term "assignment" most precisely refers to a promisee's transfer to a third party of the rights to receive the promisor's performance. "Delegation" refers to a promisor's transfer to a third party of the obligation to render the performance due to the promisee. "Transfer" of a contract by a party generally means simultaneous assignment of the party's rights and delegation of the party's duties. We use the term "assignment," however, as it is commonly used in contracting today, to refer to a complete transfer of a contract-that is, both assignment of the assignor's rights and delegation of their duties to the same third party. See E. Allan Farnsworth, 3 Farnsworth on Contracts $\$ 11.10$ (3d ed. 2004).

13. See U.C.C. $\$ 2-210(1)$ (a) (2003); Restatement (SeCond) of Contracts $\$ 317$ (1981).

14. E.g., Reynolds \& Reynolds Co. v. Hardee, 932 F. Supp. 149, 153 (E.D. Va. 1996) (Virginia law prevents assignment of executory contracts for personal services), aff'd, 133 F.3d 916 (4th Cir. 1997). In nearly all reported cases on the assignability of an employment contract, the assignee is seeking to enforce a covenant not to compete that was contained in the employee's contract with the original employer. The few cases that rule in favor of assignability typically involve situations in which the employee appears to be acting opportunistically, invoking the doctrine of nonassignability just to escape the noncompete clause. See, e.g., Evening News Ass'n v. Peterson, 477 F. Supp. 77 (D.D.C. 1979) (newscaster's contract is assignable where he accepted the assignment without objection until a competitor tried to hire him away). Consequently, these cases presumably overstate the willingness of the courts to find an employment contract assignable when an employee resists assignment of her contract simply because she wishes not to work for the proposed assignee.

15. Even when a promisor's obligations under a contract are assignable, the promisor remains liable to the promisee after those obligations have been transferred to a third party, unless the promisee specifically agrees that the original promisor will be excused from such continuing liability. We discuss residual liability further infra in Section IV.E.

16. See Restatement (Second) of Prop.: Landlord \& Tenant $\$ 15.1$ (1977).

17. See infra Appendix B, Table 1 ( 99 percent of the leases in our sample contain explicit nonassignment provisions).

18. For simplicity, we'll restrict our explicit attention here to corporate-type or "strongform" legal entities. These are legal entity forms, such as the ordinary business corporation (joint stock company), that are endowed with (1) limited liability for the firm's owner(s) (e.g., 
poration is not considered an assignment of the contract. ${ }^{19}$ The corporation, and not its shareholders, is considered to be a party to the contracts, and the corporation maintains its identity as its ownership changes. This rule is generally interpreted quite broadly. For example, the courts have held that the sale of all the stock in a closely held corporation whose principal asset is a contract does not violate a nonassignment clause even when the stock is sold to a person to whom, previously, the counterparty had explicitly refused that the contract be assigned. ${ }^{20}$ If the counterparty to a contract with a corporation wishes to limit the persons to whom ownership or control of the corcorporation can be sold, it must do this through specific language to that effect in the contract (a "change of control" clause); a nonassignment clause will not suffice.

These rules make it easy for contracting parties to provide that a given bundle of contracts will not be split up, while at the same time providing that the bundle of contracts as a whole is fully transferable. The parties need only create a corporation that is a party to all the contracts in the bundle, and ensure that the contracts are not assignable by that corporation. By selling their shares in the corporation, the owner(s) of the corporation fully transfer to the purchasers all of their rights and obligations in the contracts that make up the bundle.

The result is an enormous savings in simple transaction costs when a business is sold as a going concern. This point is obvious for publicly held business corporations. If all sales of shares in such a corporation were considered an assignment of each of the firm's contracts, with the result that many of the firm's counterparties would be relieved of their obligation to perform, then free tradability of shares would be impossible. But there are also substantial transaction cost savings for closely held firms, including firms with a single owner. If the sale of 100 percent of the stock in a corpo-

shareholders); (2) strong "entity shielding" (meaning that the personal creditors of an owner (shareholder) of the firm have no direct claim on the firm's assets, nor can they force liquidation of the firm even if the owner is in bankruptcy), and (3) transferability of shares in ownership of the firm. These three attributes are complementary and often come as a package; they are available not just with the business corporation but also with the limited liability company ("LLC"), the limited partnership, and the statutory business trust. See generally Hansmann \& Kraakman, supra note 7. For further simplicity, we'll generally focus our discussion just on business corporations. Most of the analysis we offer here, however, applies to legal entities in general, from partnerships to nonprofit corporations. The crucial element is that a change in ownership or control of the entity does not in itself constitute a breach of a contract made in the name of the entity.

19. Baxter Healthcare Corp. v. O.R. Concepts, Inc., 69 F.3d 785, 788 (7th Cir. 1995) (change of ownership of stock does not constitute a violation of the selling corporation's contractual obligations and is not an assignment of the selling corporation's interest in an agreement). See generally Note, Effect of Corporate Reorganization on Nonassignable Contracts, 74 HARV. L. REV. 393 (1960).

20. E.g., Ser-Bye Corp. v. C. P. \& G. Mkts., 179 P.2d 342, 345 (Cal. Dist. Ct. App. 1947); Branmar Theatre Co. v. Branmar, Inc., 264 A.2d 526 (Del. Ch. 1970). But see In re Alltech Plastics, Inc., 5 U.S.P.Q.2d (BNA) 1806 (Bankr. W.D. Tenn. Dec. 30, 1987) (transfer in bankruptcy of all the stock of a corporation whose only asset is a patent license constitutes an impermissible assignment of the license). 
ration from one sole owner to another were considered an assignment of the corporation's contracts, then explicit consent to the assignment would have to be sought one by one from a large fraction of the firm's counterparties. This consent might be obtained at the time of the sale of the business. Alternatively, consent to future assignments might be included as a term in the original contract between the firm and the counterparty. (We will say more about consent to assignment below. ${ }^{21}$ ) Either way, obtaining the consentsor failing to get them-would increase substantially the transaction costs of making the business transferable as a going concern.

There is more involved here, however, than the basic transaction costs of drafting and negotiating contracts (large as those costs may be). The full scope and structure of the costs avoided by disassociating the sale of a legal entity from assignment of that entity's contracts is much more substantial than is commonly recognized. Our theory of bundled assignability seeks to make those cost savings clear. We first offer a simple intuitive explanation of that theory, and then provide a more precise exposition by way of a numerical example.

\section{B. A Sketch of Our Theory}

Our theory starts with the observation that a legal entity is, quite literally, a "nexus of contracts" in the sense that it serves as the common party to the many contracts-with suppliers, employees, and customers-through which the firm does business. In many cases, the most important assets that the firm holds are its contractual rights.

Consider, for example, the movie rental company Netflix. The value of Netflix is based largely on its assemblage of contractual relationships. The DVDs that Netflix rents to its customers are acquired via contractual agreements with the major movie studios. These contracts require Netflix to make a small up-front payment to the studio for each DVD, and then contingency payments based on the number of times the movie is rented. Netflix also provides streaming video to its subscribers by licensing content owned by movie studios using similar revenue-sharing and fixed-fee agreements. All of the real estate that Netflix occupies is obtained through long-term leases. Most of the firm's revenues come from its pool of subscriber contracts. ${ }^{22}$

\section{See infra Section III.E.}

22. In the Netflix example, the transition from purchasing DVDs and owning them outright to negotiating revenue-sharing contracts was crucial to the growth of the company. According to the company's founders, these agreements made it less risky for Netflix to expand its catalog of DVD titles to include less popular titles, which, in turn, led to growth in its subscription base. In theory, of course, Netflix could have negotiated with studios on a caseby-case basis and agreed on different purchase prices for different titles, with lower prices for less popular movies. They also could have used third-party financiers to acquire the capital necessary to make these purchases. But we suspect that the device Netflix ultimately chose involved lower negotiation costs; it also may have been more sensible, if the studios had superior information about the rental value of each title, to give them a stake in the rental payments. A complete theory would endogenize these bilateral contracting arrangements, but we do not make a complete attempt to explain their existence in the theory we develop here. 
A noteworthy feature of these contractual agreements between Netflix and its counterparties (content suppliers, landlords, employees, managers, customers, et cetera) is that they are bilateral executory contracts-that is, they create both rights and obligations for Netflix, making the contracts simultaneously both assets and liabilities for the firm. The potential for twosided opportunism that flows from such contracts gives rise to the theory of entities that we develop in this Article.

For simplicity, and to emphasize the theory's application to subsidiaries, we focus on a business with a single owner, which may be an individual or a corporation. We assume that the business's contractual rights contribute importantly to its value. More particularly, we focus on environments in which the business's contractual counterparties are largely unconcerned with the identity of the owner of the business. Rather, they are concerned with the business's other contractual relationships. Counterparties might depend on the quality of the other contractual counterparties. Most obviously, a transfer of a customer contract to a firm that uses lower-quality inputs might result in lower-quality output for the customer. The difference in quality might be important to the customer but difficult to describe in a contract and difficult for a court to verify after the fact. We will call this the nonverifiable quality problem. This problem affects contracts with suppliers as well as with customers. For example, the owner of a high-class shopping center may care about the quality of a shoe store to which he leases space. In particular, he may be concerned about the personal qualities of the individual hired to manage the store, the character of the manufacturers whose shoes the store is licensed to sell, and the quality of the advertisements that the store places in various media. Consequently, the landlord will not want the owner of the shoe business to be able to assign the store lease to a different retailer who sells cheap merchandise, creating negative externalities for the shopping center as a whole. But, again, it may be difficult for the landlord and the business owner to specify in the lease a set of verifiable characteristics that describe the firms to which he would be willing to have the shoe store assign its lease.

Another reason for a business's contractual counterparty to care about the character of the business's other counterparties lies in credit risk. Consider again the owner of the shopping center. He does not want to give a long-term lease to a retailer that holds a highly valuable franchise-and thus is virtually certain to be capable of paying rent for the full term of the contract-only to have the lease assigned to another retailer with a franchise that is extremely shaky, creating the risk of default on the lease. And, as with quality, it may be very difficult to specify in the lease the characteristics of the assignees that the landlord would consider acceptable credit risks. We will call this the credit-risk-transfer problem.

For a formal theory that justifies revenue sharing in the video rental context, see James D. Dana, Jr. \& Kathryn E. Spier, Revenue Sharing and Vertical Control in the Video Rental Indus. try, 49 J. INDUS. ECON. 223 (2001). 
Because of the nonverifiable quality problem and the credit-risk-transfer problem, if a contract is freely assignable there is a risk that the owner of the business will opportunistically assign the contract, in return for a handsome profit, to another business whose low quality or high credit risk would otherwise prevent it from obtaining the contract on such favorable terms. Or the business owner might simply threaten such an assignment, and hold up the counterparty for payment not to do it. It follows that, if contracts are freely assignable, counterparties will charge higher prices to cover their risks or refuse to contract with the firm entirely. Consequently, both a business firm and its principal contractual counterparties may very well want to prevent their contracts from being assigned away from the firm's existing bundle of contracts without their consent.

At the same time, the owner-we can realistically assume-would like the ability to sell the business in case she needs liquidity (that is, funds to use for other expenditures or investments) or in case some other owner can control the business more efficiently. If, however, the owner is herself the signatory on all of the business's contracts - that is, the business is formed as a sole proprietorship, so that the proprietor is herself the firm, or the business is organized as an unincorporated division of a larger corporation-then sale of the business requires assignment, from the current owner to the purchaser, of all of the business's contracts. And if, for the reasons just surveyed, the business's most important contracts are nonassignable, this will require explicit permission from the counterparties to each of these contracts. The shoe is then on the other foot, with the counterparties in a position to hold up the owner of the business for most or all of the potential gains from the business's sale. ${ }^{23}$ Foreseeing that she will be forced to share the gains from her investments with her counterparties in the event of a sale, the owner will have reduced incentives to make specific investments that create value for the business. She may not expend sufficient effort in the first place to assemble a highly complementary set of contracts that will constitute the core of the business's value.

When combined with the law's default rules on assignability of contracts, a legal entity such as a business corporation provides a convenient means for mitigating all of these problems. ${ }^{24}$ In particular, as we have seen, through the use of corporate entities it is easy to create bundled assignabil-

23. Practitioner publications have noted the risk of a holdup problem when contracts do not permit bundled assignability. See, e.g., Albert J. Li, Understanding Anti-Assignment Clauses and Their Implications on Your Acquisition (DLA Piper Rudnick Gray Cary US LLP, Austin, Tex.), July 3, 2004 ("Failure to pay close attention to the operative language while the contract is being negotiated may create the opportunity for the non-transferring party to extort concessions in return to its consent to the contract assignment .... The target may well have lost the ability to assure the closing of a sweet deal for the entire company as a result of one contract.").

24. The ability to avoid antiassignment provisions in key contracts by structuring transactions as stock sales is well known by legal practitioners. See, e.g., John N. Gavin et al., The Transfer of a Health Insurance/Managed Care Business, J. HEALTH CARE Fin., Winter 2007, at 10 . 
ity: the packaging of contracts into bundles such that a given contract cannot be assigned individually but can be assigned together with all of the other contracts in the bundle.

To illustrate the intuition behind our results, we present a numerical example in the next Part. The example illustrates the economic benefits of bundled assignability in mitigating the bilateral opportunism problems described above.

\section{A Numerical EXAMPLE OF THE THEORY}

Our numerical example focuses on the owner's relationship with her input suppliers and the credit-risk-transfer problem that those suppliers confront. Most of the underlying logic applies as well to the nonverifiable quality problem. We focus on the credit-risk-transfer problem simply because it lends itself more intuitively to quantification. The key to both problems is that the expected quality of performance to the firm's contractual counterparties depends on the identity and quality of the firm's other inputs: the owner has an incentive to opportunistically transfer a given contract to a firm with lower-quality inputs, making a profit on the transfer. As a result, counterparties ask for protection by bundling their contracts with the firm's other inputs, ensuring that they will benefit from the creditworthiness and quality of performance promised by that combination of complementary inputs.

Consider the following numerical example. For concreteness, the example focuses on a fictional business, Patriot Beer, which makes high-quality, microbrewed beer. ${ }^{25}$ Marion, the owner who started the business, developed a formula for making a smooth, rich-flavored beer. (Marion could be a fleshand-blood individual or a business corporation; our analysis applies equally.) To produce the beer, Marion established contractual relationships with five key parties: a supplier of glass bottles, a supplier of ingredients, a manufacturer that produces the beer according to the company's specifications, a distributor to transport the beer to bars and restaurants, and a landlord from whom she leases the office space for the company headquarters. In reality, of course, a beer maker will have many more contracts and will own outright some of the assets used in production. We assume that all inputs are obtained by contract simply to illustrate clearly the novel aspects of our theory; we keep the number of contracts to five so that the math stays manageable.

The goal of our numerical example is to demonstrate the potential benefits of organizing the Patriot Beer business to make the beer contracts "bundled assignable" rather than individually assignable. In other words, the most efficient economic configuration is one that allows Marion to assign

25. The fact pattern is based, very loosely, on Boston Beer, the maker of Sam Adams. Prior to 2007, nearly two-thirds of the beer sold by the company was produced by third-party brewers through contractual relationships, and the company had contractual relationships for all its other inputs, as the example suggests. See Boston Beer Co., Annual Report (Form 10-K) 33-35 (Dec. 26, 2009). 
the Patriot Beer contracts freely to a new owner, but only as a bundle. ${ }^{26}$ For the sake of exposition, we will assume that all of the contracts required for making Patriot Beer are signed by Patriot, a separate corporate entity that is wholly owned and controlled by Marion, regardless of whether the contracts are individually assignable or bundled assignable. ${ }^{27}$ Also, for the purposes of this example, when we say that a contract is "assignable," we take the linguistic liberty of meaning that all of the assignor's rights and obligations under the contract can be transferred to an assignee free of any residual liability for the assignor. ${ }^{28}$

We focus particularly on Patriot's contract with the bottle supply company. In principle, however, the same incentives could affect any of Patriot's contractual partners, as long as they provide credit along with their supplies or services. Moreover, the owner would face the same incentive problems with respect to the bottle supply contract if the other inputs are assets owned outright. ${ }^{29}$

Suppose that there are four important dates: 1, 2, 3, and 4. At Date 1, Marion assembles the five contracts required to produce beer. At Date 2, Marion decides whether to invest in specializing Patriot's relationships with its suppliers for the purpose of making those relationships more productive. At Date 3, before any supplies are received or any production begins, Marion can decide whether Patriot should make adjustments, such as assigning her contracts with her initial suppliers or replacing them with new suppliers. In particular, if Marion needs liquidity, she can cash out by selling (assigning) some or all of the assembled contracts. Date 4 captures the final stage, when the outcomes of the decisions made through Date 3 are realized. Suppliers provide their inputs and beer is produced and distributed. The beer is then sold and the firm receives payment for it. At this point, the firm ceases production, pays off its obligations, and returns any leftover income to its owner/shareholder. The firm then dissolves.

26. Again, though we use the pronoun "her," Marion could very well be a corporation.

27. We postpone to Part VI our discussion of why the creation of a separate legal entity is a more effective way to create bundled assignability than if Marion signed these contracts in her own name.

28. We discuss residual liability infra in Section V.E. Also, to focus squarely on issues involving assignment of contracts and bundling, we temporarily postpone analyzing any effect that the owner's other assets and liabilities might have on the problem. Suppose Patriot Beer were organized as an unincorporated division of the Marion Corporation instead of as a separate subsidiary, and suppose also that Marion owns and operates an unincorporated spirits division. The suppliers to Patriot Beer might value the ability to attach the assets in the spirits division if Patriot defaults on its obligations. Conversely, they might be concerned that the creditors of the spirits business might attach the assets in Patriot Beer if the spirits business defaults, thus reducing the likelihood that Patriot's suppliers receive full payment. Placing Patriot Beer in a separate subsidiary entity provides more separation of the assets and liabilities of the beer and the spirits businesses, and this might affect the owner's decision problem. We take up these important asset-partitioning issues in the next Section.

29. To focus clearly on incentives, we assume that all parties are risk neutral. We also assume, for simplicity, that the time rate of discount is zero. 
To understand assignability of contracts in this example, we must have some form of credit risk, as well as a potential assignee. Thus, we will assume that beer makers may fail and become unable to pay off their suppliers. Concretely, suppose that if any beer maker (including Patriot) succeeds it receives a cash flow of 100 at Date 4, but if it fails it receives a cash flow of 0 .

Beer makers differ in their probability of success. Because Marion conducted a thorough search and identified high-quality supplies that are ideally designed to make best use of Patriot's premium formula for beer, Patriot has a high probability of success. In particular, suppose that Patriot's probability of success, after assembling the bundle of inputs, is 0.95 . This captures the fact that the original assembly of inputs is high quality and/or complementary, and thus the best suited to producing Patriot Beer. The distributor, for example, might be physically located near the brewing plant, minimizing delivery costs. Or it might have the special skills needed to market and distribute premium beer.

A second beer maker, Milwaukee's Worst ("MW"), is a fly-by-night company that uses cheap, standardized ingredients and a standard brewing formula, and consequently makes lower-quality beer. Because its owners did not exercise a great deal of care in assembling its supply relationships or monitoring their quality, MW has poor future prospects. In particular, suppose that its probability of success, using its current inputs, is only 0.5 . Since MW does not attempt to produce a specialized product, we suppose that MW can change any of its inputs without affecting its probability of success.

\section{A. Investments in Complementarities}

After assembling the inputs at Date 1, Marion has the opportunity at Date 2 to make an additional investment that further enhances the complementarity of the inputs-that is, an investment that makes the various inputs more valuable as a bundle. To give a concrete example, suppose that Patriot uses a real-time inventory system that keeps the bottling company informed about the quantities of bottles needed for the upcoming month. While the investment could be used with another bottler, the time spent installing the software at the current bottler's headquarters and training the employees at the current bottler to use and respond appropriately to the information would be specific to that bottler, increasing the complementarity between Patriot and the bottling company. If a replacement bottling company were found, that effort and expense would need to be replicated with the replacement's employees. This makes the initial bottler more valuable than a replacement once this costly investment is made. At the same time, if the bottling contract were transferred to MW and MW did not-as we assume-use this inventory management system, the investment would be of no use to Patriot. 
Suppose that Marion can choose whether to invest 2 in the training of the bottler's employees to use the inventory software. ${ }^{30}$ If the investment is made and the bottle supplier is kept in place, we suppose that Patriot's probability of success increases from 0.95 to 1 . If the investment is not made, then the probability of success will be 0.95 , whether the supplier is replaced or not. In other words, the investment is required to make the bottle supplier fully complementary with the rest of Patriot's operations; if the investment is not made, then all bottlers are identical.

Given our assumptions about the costs and benefits, the investment is valuable. It costs 2 , but it raises the probability of success by 0.05 . Since success pays 100, the expected gross benefit of the investment is $0.05 \cdot 100=5$, and its net benefit is $5-2=3$.

\section{B. Contracts and Assignability}

Patriot signs long-term contracts with each of its five suppliers. These contracts provide that the relationship will remain in place from Dates 1 to 4 , so that the suppliers cannot terminate at Date 3 without breaching their contract. This long-term commitment of suppliers is valuable to Marion because she plans to make long-term investments in Patriot that will use these particular suppliers. The long-term contracts, then, protect the owner against the now-familiar "holdup problem." A supplier might opportunistically threaten to withdraw his input after Marion makes her investments in Patriot and use this threat to extract from Marion some of the value of those investments.

The potential holdup problem by suppliers also gives Marion an incentive to make the bundle of contracts freely transferable in some form-at least as a whole - so that Patriot can be sold without the consent of the suppliers. Suppose, in particular, that Marion anticipates that she might have liquidity needs at Date 3 , or that Patriot might have more value under a new owner at Date 3, and thus that she will wish to sell Patriot at that date. Requiring the consent of her suppliers to transfer the bundle to a new owner would lead to a holdup problem, in which suppliers agreed to consent only if they received some of the gains of her investments. Given that Marion will want to avoid the potential for this holdup problem, we will focus on alternatives that allow for free transferability of the bundle of contracts at Date 3 .

30. We assume, as is standard in the economic theory-of-the-firm literature, that this investment is noncontractable. If, on the contrary, the suppliers could somehow require the owner to make this investment and specify its terms completely in a contract, then it would not be important whether the bottle supplier's contract were assignable. It is, however, realistic to assume that there are often important components of the investment decision that are noncontractable (how hard the owner works to implement the software, the amount of time spent training employees, et cetera). 


\section{Credit Risk}

Let us assume that supply and demand in the market for supplies is such that each supplier (of bottles, hops, et cetera) requires an expected payment of 10 in exchange for supplying his input. To assure that the suppliers have a strong incentive to perform well (or, alternatively, because Patriot does not have good access to other sources of financing), the suppliers will be paid only at Date 4 . This means that, prior to Date 4 , the suppliers are creditors of Patriot.

Given that the expected payment must equal 10, the bottle supplier must ask for a payment larger than 10 to compensate for the risk of default if there is any chance that the beer company will fail. In particular, if the supplier expects to be paid by a beer maker that has probability of success $p$, then the supplier must contract for a repayment of $10 / p$ at Date $4 .{ }^{31}$ Thus, if each supplier expects that Patriot will be responsible for repaying him, that Patriot will use all of its original contracted inputs, and that Marion will make the inventory investment, then each supplier will demand exactly 10 in repayment at Date 4 , since success is certain under these conditions. If, alternatively, a supplier contracts with a beer maker, like $\mathrm{MW}$, whose probability of success is known to be only 0.5 , then the supplier will insist on a promise of repayment of $10 / 0.5=20$ at Date 4 .

\section{Investment with Bundled Assignability}

Suppose, first, that Patriot promises all five of its suppliers that all of their contracts, if assigned at Date 3, will be kept together as a bundle, and thus cannot be individually assigned. We can now analyze Marion's incentive to make the investment in the inventory management software. We would expect Marion to make the decision that maximizes the value of her ownership of Patriot, net of the cost of any investment.

The value of Patriot to Marion is the expected net payment that Patriot will receive at Date 4 if the business succeeds and pays off all of its suppliers. ${ }^{32}$ Suppose that the suppliers anticipate that the investment will be made. (This belief will be confirmed by Marion's decision, as we will see) ${ }^{33}$ If so, they will demand a contract price of 10 , since Patriot would succeed for sure if these beliefs hold true.

31. The supplier will be repaid in full with probability $p$ and paid nothing with probability $(1-p)$, since the cash flow in failure is zero. So if the supplier demands a repayment of $10 / p$, then his expected repayment will be $p \cdot(10 / p)+(1-p) \cdot 0=10$, which is his required expected payment.

32. We assume that a buyer would be willing to pay the full expected value of Patriot's cash flows at Date 3 if Marion decides to sell, so Marion's future payoff does not depend on whether she has liquidity needs.

33. In any equilibrium, suppliers must have a contract price that gives them an expected repayment of 10 , given their beliefs about Marion's future behavior, and Marion's behavior must be consistent with the suppliers' beliefs. Under nonassignable contracts, Marion chooses to invest-hence, the contract price of 10 is consistent with equilibrium behavior. 
If Marion makes the investment, the value of her equity ownership in Patriot, net of the investment cost, will be $1 \cdot(100-5 \cdot 10)-2=48$. If, on the other hand, she chooses not to invest, Patriot to her is worth $0.95 \cdot(100-$ $5 \cdot 10)=47.5<48$. Given that the payoff is larger when Marion invests, she will make the investment and, net of the investment cost, Patriot will be worth 48 to her.

\section{E. Investment with Individual Assignability}

Now suppose that the Patriot supply contracts can be assigned individually. Marion then faces a different decision. In addition to deciding whether to invest, Marion must also decide whether to keep the bundle intact or assign the bottle supply contract individually to MW. Suppose that, in this situation, suppliers set their contract prices on the assumption that Marion will not invest and will assign the bottle supplier's contract. (Again, as we will show, these beliefs are consistent with Marion's incentives and thus will be confirmed by her behavior.) Thus, anticipating no investment, the other suppliers expect Patriot to succeed with a probability of 0.95 . As a result, they will demand a contract price of $10 / 0.95=10.5 .^{34}$ The bottle supplier, expecting assignment to MW, will insist on a contract price of $10 / 0.5=20$. $^{35}$

Given these supply costs, now consider Marion's incentives to assign the bottle supplier's contract. First, suppose she has invested in the software. At first glance, it might appear that there would be no incentive to assign the bottle supply contract after investing in it, because this would mean that a less complementary replacement supplier must be substituted. That loss of complementarity, in turn, would reduce the probability of success from 1 to 0.95, hurting both Marion and the remaining suppliers. Moreover, MW doesn't increase its probability of success by using Patriot's bottle supplier. This means that it is economically inefficient for Marion to assign the bottle supply contract to MW: the result would be to decrease Patriot's probability of success without improving MW's. In fact, however, Marion does indeed have an incentive to assign contracts opportunistically notwithstanding this social inefficiency.

34. We assume that all bottlers are identical in the absence of the investment by Marion. Hence, Patriot can find a replacement bottler of the same quality, and the probability of success remains at 0.95 . We discuss the possibility that the initial bottler is specialized to Patriot, even in the absence of investment, infra in Section IV.B.

35. It is also possible to show that it would not be an equilibrium for suppliers to agree to a contract price of 10 , anticipating that assignment will not occur. If suppliers set a contract price of 10, Marion will have the incentive to assign to MW for a positive price.

That the bottle supplier sets its contract price at 20 , expecting with certainty assignment to $\mathrm{MW}$, results from the simplicity of the setup. In a richer model, there may be some probability that Patriot cannot find an assignee like MW, or the bottle supplier might renegotiate with Patriot under the threat of assignment. In either case, the initial contract price will be less than 20. But if the contract price is less than 20, the opportunistic assignment problem will continue to occur, because MW will be willing to pay Patriot for the improvement in its contract terms. 
Marion's private incentive to assign the bottle supplier arises from the ability to replace this supplier, who demanded a high contract price of 20 owing to the assignment threat, with a supplier who will accept a lower contract price under a promise not to assign. After Marion assigns the original bottle supply contract to $\mathrm{MW},{ }^{36}$ she has the incentive to promise the replacement bottler that his contract will remain bundled with the other input contracts. If the contract is individually nonassignable, the replacement bottler will demand 10/0.95, the same contract price as the remaining suppliers.

In our numerical example, Marion's gain from the lower contract price outweighs the lower probability of success. If Marion invests, but chooses not to assign, she will receive $1 \cdot(100-4 \cdot(10 / 0.95)-1 \cdot(10 / 0.5))-2=36$. If Marion invests and chooses to assign, she will receive $0.95 \cdot(100-$ $5 \cdot(10 / 0.95))-2=43$. Thus, if Marion invests, she nonetheless prefers to assign the supply contract rather than keep it. While it is costly to Marion to replace a superior input with an inferior one, this loss is more than made up by the benefit received from opportunistically assigning the contract.

This gain to Marion from assigning the bottling contract is not a real economic gain. Rather, it is merely a redistribution of value from Patriot's supplier/creditors to its owner, Marion, by shifting credit risk-here the risk of the firm's complete failure-to the suppliers. Owing to the assignment to $\mathrm{MW}$, the expected value of the payment promised the original bottle supplier falls, as of Date 3, from 20 to $0.5 \cdot 20=10$. The other four Patriot suppliers also lose, albeit a smaller amount: the value of each of their contracts falls from $10 / 0.95=10.5$ to $0.95 \cdot(10 / 0.95)=10$, due to the lost complementarity. In total, the five original Patriot suppliers lose 12 (the bottle supplier loses 10 while the other four suppliers lose 0.5 each), and Marion gains $43-36=7$. On net, the total losses (12) exceed the gains (7). The net loss of 5 is exactly the expected loss in reducing Patriot's probability of success from 1 to .95 , which creates a net expected loss to society of $0.05 \cdot 100=5$.

The preceding discussion shows that, if Marion makes the investment, she prefers to assign. But if this is true, it is clear that Marion will never prefer to make the investment. After all, the value of the investment will be lost when the bottle supply contract is assigned. Marion can save herself the investment cost, and obtain the same benefit from opportunistic assignment, by simply choosing not to invest at the outset. If she doesn't invest and instead assigns, she receives $0.95 \cdot(100-5 \cdot 10 / 0.95)=45$. Since 45 is the

36. In this numerical example, MW would be a willing assignee of Patriot's supply contract, without giving or receiving compensation from Patriot. After all, a bottle supplier contracting with MW would demand a contract price of 20 , which is exactly what Patriot's contracting party demands. Thus, MW is indifferent between being an assignee of Patriot's supply contract and contracting on its own.

For simplicity, we are assuming in this example that all bargaining power lies with Patriot when Patriot contracts with its five suppliers or contracts with MW. Hence, in the assignment to MW being discussed here, MW is left no better off than it was before and Patriot receives all of the gains from the transaction. Results are similar, however, if bargaining power is shared between the parties. 
highest possible payoff for Marion of the four possible choices when contracts are assignable, ${ }^{37}$ she will choose not to invest and to assign. ${ }^{38}$

\section{F. Comparing Individual and Bundled Assignability}

Let us assume that, when entering into contracts for Patriot at Date 1, Marion understands the preceding calculations of her expected returns from Patriot. Then Marion knows that bundling the supply contracts together gives her an incentive to make the investment, and hence (as we saw above) produces a payoff of 48 . This is higher than 45 , the highest payoff she would receive if the contracts were individually assignable. The difference between the two payoffs, $48-45=3$, is the net social value of the investment.

The reason why Marion's private return is equal to the social gain from the investment is that we have assumed that all of Patriot's suppliers also understand the preceding calculations and therefore price Marion's expected behavior into their contracts. This means, in turn, that the cost of any social inefficiency is borne by Marion at the end of the day. Thus, given a choice about how to arrange the bundle at the outset, Marion will choose to sign contracts with her suppliers that are bundled assignable-that is, the contracts will prohibit assignment of any one contract apart from the other contracts in the bundle. This contracting structure gives Marion the incentive to make the decision that is consistent with both social and private efficiency.

In sum, this simple example demonstrates that bundled assignability can offer important advantages over the two basic alternatives: complete nonassignability on the one hand and individual assignability on the other. It remains to be asked how bundled assignability is achieved in practice, and particularly whether legal entities such as the business corporation are necessary or sufficient for that purpose. Before addressing that issue, however, we consider the degree to which the conclusions we have drawn from our numerical example depend on the assumptions we have made in constructing that example.

\section{Consequences of Changing the Assumptions}

All theories rely on assumptions, and our theory is no exception. But the main result we have described here-that bundled assignability can be supe-

37. Marion's payoff if she does not invest and does not assign is $.95 \cdot(100-4 \cdot 10 / 0.95$ $-1 \cdot 10 / 0.5)=36<45$.

38. For the moment, we are not allowing the parties to renegotiate in the shadow of a potential assignment. We show infra in Appendix A.4 and supra in Section IV.D that free assignability also weakens incentives to invest in the presence of renegotiation, as long as the supplier has some bargaining power in renegotiation. If the supplier does have bargaining over the assignment decision, then the supplier will extract some of the value of Marion's investment, the prospect of which will weaken Marion's incentive to make the investment in the first place. 
rior to individual assignability in creating and preserving the value of the bundle that constitutes a firm-is remarkably robust when we vary the assumptions made in the numerical example above. In this Part, we consider several changes to our assumptions, and explain why our results do not depend on these changes. In Appendix A, we modify the numerical example of Part III to reflect each of these alternative assumptions in turn, and show that the results we derived in Part III are robust to these changes.

\section{A. Bundling Contracts with Assets Owned Outright}

Our results do not depend on the assumption that all of Patriot's inputs are obtained by contract rather than owned outright by the firm (as one might expect, for example, with machinery). As long as one of the inputs is acquired via a bilateral contract, there may be value in bundling that input with the firm's other inputs. Marion has the same incentive to opportunistically assign a bilateral contract to a less creditworthy firm even if the other inputs are assets she owns instead of contracts. As before, the opportunisticassignment motive reduces Marion's incentive to make valuable investments in complementarities between the contract-based input and the firm's other inputs. Knowing that any inefficiency is ultimately reflected in the value of her ownership of Patriot, Marion has an incentive to tie the contract to the firm's other inputs, whether they are contracts or assets owned outright. ${ }^{39}$

\section{B. Other Sources of Complementarities}

The benefits of bundling also do not depend on the assumption that the complementarities between the inputs flow from an investment made by Marion after the inputs are assembled. The bottle supplier might be worth more with Patriot for reasons that have nothing to do with Marion. For example, the bottle supplier might be physically located near the Patriot brewery, minimizing delivery costs. As long as there is some potential for an inefficient and opportunistic individual assignment to occur at Date 3, Marion will have the incentive to commit herself to avoiding this inefficiency by bundling complementary inputs at the outset. ${ }^{40}$

\section{Other Sources of Inefficient Assignment}

Our example assumes that an individual assignment is socially inefficient because the inputs are complementary: that is, they are worth more together than apart. But there might be other reasons why separation of inputs is inefficient. As an example, if Patriot's contracts are individually assignable, Marion might spend valuable time and energy searching for opportunistic, high-risk assignees like MW instead of adding value to the business. Just as it is in Marion's interest to commit to keeping complementary inputs together, it is also in Marion's interest to commit to her counterparties at Date 1 that

39. See infra Appendix A.1 for a numerical example.

40. See infra Appendix A.2 for a numerical example. 
she will not incur these wasteful expenditures. Bundling contracts together is a way to achieve this commitment. ${ }^{41}$

\section{Renegotiation in the Shadow of Assignment}

In the example above, when we assumed that contracts were individually assignable, we did not allow Marion to renegotiate with the bottle supplier under the threat that she would assign his contract to $\mathrm{MW}$; we simply assumed that she would assign the contract if doing so offered her a profit. Yet both parties would have an incentive to renegotiate. Investment specializes the bottle supplier to the other inputs in Patriot, making the bottle supply contract worth more when bundled with Patriot than with $\mathrm{MW}$. If Marion invests, an individual assignment to $\mathrm{MW}$ would be inefficient. Given this potential inefficiency, both parties would be better off if Marion were to agree not to assign the bottle supplier's contract in return for a payment from the bottler that is less than what the bottler would lose from assignment, but greater than what Marion would gain. An inefficient assignment would thereby be avoided.

A first objection to this kind of renegotiation might be that it virtually never occurs, presumably because a merchant that tries to extract payments from suppliers by making such opportunistic threats will quickly get an intolerably bad reputation. But even if we assume that such renegotiation will occur-as economic modelers often do-individual assignability will continue to produce weaker investment incentives for Marion than will bundled assignability. The weaker investment incentives follow because Marion's investment in complementarities between the bottle supplier and the other inputs creates a surplus over which the parties can bargain. As long as the bottle supplier has some bargaining power in renegotiation, he will capture some of this surplus when the two parties bargain to a new agreement that keeps the bundle together. Since, as a consequence, Marion does not capture the full value of her investment, she will have less incentive to make the investment in the first place. ${ }^{42}$

\section{E. Residual Liability}

The default rule of contracts is that a party who assigns (or more formally, "delegates" 43 ) her contractual obligations to a third party remains residually liable, as a surety, to her original contractual counterparty in case the assignee fails to perform. The assignor can be relieved of that liability only if (1) at the time of the assignment, the counterparty explicitly agrees (via a "novation" of the contract) that the assignor will be relieved of residu-

\footnotetext{
41. See infra Appendix A.3 for a numerical example.

42. See Appendix A.4 for a numerical example.

43. See supra note 12.
} 
al liability ${ }^{44}$ or (2) the original contract specifically provided that, if the contract were assigned, the assignor would not retain residual liability. ${ }^{45}$ In our numerical example, we consider only the two polar extremes - on the one hand, contracts that are completely nonassignable by the firm and, on the other hand, contracts that are completely assignable, in the sense that the assignor (Patriot in our example) bears no residual liability if the assignee (MW) fails to perform all of the contractual obligations originally undertaken by the assignor (which in our example means payment in full of the agreed-upon price to the bottler).

It might at first seem that, if the assigning party were to retain residual liability for the performance of the contractual obligations it originally assumed (as the default rule of contract law, in fact, provides), the result would be to obviate the need for bundled assignability. Imagine, for example, that Patriot had the right to assign each supply contract separately, but that-contrary to the assumption we have made in the model above-Patriot remained residually liable to any supplier whose contract it assigned. Marion would then have less incentive to assign the bottler's contract to MW, since the assignment would not be as successful in avoiding any payments due to the bottler under the contract. On the contrary, such an assignment might be costly to Marion, since she would also internalize the costs of losing the higher productivity achieved if the bottler works with Patriot rather than MW. It follows that, if Marion were to need liquidity, she would have an incentive to sell the whole firm as a unitthat is, to assign all five supply contracts to a single purchaser.

So we might think that individual assignability of contracts, combined with residual liability for the assignor, could preserve the incentive for Marion to assign complementary contracts only together in an efficient bundle-which, in turn, would provide the appropriate incentive for Marion to make efficient investments that will further specialize the suppliers' contracts to each other. But residual liability has several weaknesses, both from Marion's perspective and from the perspective of the firm's counterparties.

From the counterparty's perspective, residual liability is imperfect because it provides only a partial solution to owner opportunism. While residual liability might mitigate the credit-risk-transfer problem that is the subject of our numerical example, it will not solve the other problem to which bundled assignability is addressed, namely the nonverifiable quality problem. A customer who contracts with a particular owner in part because the owner's business sells high-quality goods might find that his contract has

44. See Rosenberg v. Son, Inc., 491 N.W.2d 71, 74 (N.D. 1992) (original franchisee liable to franchisor on franchise contract that had twice been resold); FARNSWORTH, supra note $12, \S 11.11$.

45. The majority view in the case law is to consider as valid a party's consent in the original contract to release the counterparty from residual liability should the counterparty subsequently assign the contract. See, e.g., Fay Corp. v. BAT Holdings I, Inc., 646 F. Supp. 946, 952 (W.D. Wash. 1986), aff'd sub nom. Fay Corp. v. Frederick \& Nelson Seattle, Inc., 896 F.2d 1227 (9th Cir. 1990); Chiarello v. Axelson, 76 P.2d 731, 733 (Cal. Dist. Ct. App. 1938). 
been assigned to another supplier who produces lower-quality goods. To the extent that this difference in quality is difficult to specify in a contract in a way that a court can verify, residual liability will not provide a remedy.

Moreover, while residual liability provides some protection to a counterparty against credit risk transfer, it is unlikely to provide the same protection as a direct claim against a going concern, which is what bundled assignability offers. If Marion sold Patriot by assigning the five contracts for money (whether as a bundle, or individually in some form), the counterparties would--under the default rule of residual liability - have claims against the proceeds of the assigned contracts held by Patriot. Marion would have strong incentives to take actions that would lessen the value of these residual claims against the pool of money, and would have many options for doing so. For example, Marion could dissolve Patriot and have its cash paid out to Marion as a liquidating distribution. ${ }^{46}$ Marion could also have Patriot invest the proceeds in a high-risk venture. Such efforts at claim dilution face any creditor of a going concern, of course, but they are more severe when the underlying assets are easily fungible, like the cash or securities received in an asset sale. Suppliers to a going concern are also better able to monitor the activity of that concern than they are able to monitor a firm-in particular, the former owner of the going concern-with which the supplier has no ongoing relationship other than that the firm remains a surety to the supplier.

Residual liability is also problematic from Marion's perspective. If residual liability is to be effective in shielding counterparties from the credit-risk-transfer problem, it will also necessarily restrict Marion's liquidity when Marion wants to assign the bundle of contracts and spend the proceeds. To provide an effective guarantee to the counterparty in a freely assignable contract, as we have seen, Patriot would not only need to promise that it remains residually liable on the contract, but Patriot would also need to make a credible promise to retain enough assets to make good on the counterparty's claim if the assignee breaches. And, even if there were an effective mechanism for making such promises credible, the consequence of the commitment would be to limit severely Marion's ability to use the proceeds from the sale until the assigned contracts expire. ${ }^{47}$ That is, as

46. There are of course legal limits on such opportunism, but they are necessarily imperfect. For instance, Delaware corporation law makes shareholders who receive a liquidating distribution personally liable for three years after that distribution for debts owed by the corporation. DEL. CODE ANN. tit. $8 \$ \S 278,281-282$ (2011). But after three years, that liability disappears, creating an opportunity. See, e.g., Riley v. Murdock, 828 F. Supp. 1215, 1220 (E.D.N.C. 1993) (dismissing, as brought beyond the three-year limit, employee's action to recover under Delaware General Corporation Law $\$ 278$ funds looted from a pension fund and then distributed by subsequently dissolved corporation).

47. One could imagine efforts to get around this. For example, Marion might agree to hold the cash proceeds from the assignment for the benefit of the bottle supplier, and borrow against them to satisfy her liquidity needs. Presumably, Marion would also need to find a way to guarantee that this personal borrowing could not be senior in priority to the residual liability claim of the supplier, or else the bonding value of residual liability would be lost. If this were feasible (which is not at all certain), an outside lender might be willing to lend against this pool of cash with a junior claim to the residual claims of the suppliers. But in reality, problems 
Patriot's residual liability is made a more credible safeguard, there is a proportionate decline in the amount of liquidity that Marion obtains from the ability to sell her contractual rights.

Even if Marion has no immediate need for liquid funds, she has other reasons to limit exposure to residual liability claims after a sale of Patriot. The value of the residual liability claim will depend on the subsequent actions and efforts of the assignee and the counterparties, which would be out of Marion's control. In economic language, Marion would be subject to a moral hazard problem. The assignee would not internalize the cost that failure of its business would impose on Marion. The counterparties might not monitor the assignee as intensely, knowing they could recover from Patriot. These economic inefficiencies would ultimately be borne by Marion, so Marion would prefer a contracting solution that avoids them. ${ }^{48}$

In short, owners will value the ability to transfer a bundle of contracts in a way that does not give rise to residual liability. Bundled assignability can provide Marion with the best of both worlds in a way that individual assignability with residual liability cannot; Marion can assure her counterparties by bundling their contracts together, and satisfy her liquidity needs in a way that limits moral hazard simply by selling her interest in the entity.

\section{F. The Parent Company Has Other Assets and Liabilities}

Suppose that Marion is a parent corporation that owns, in addition to $\mathrm{Pa}$ triot, a spirits business with its own set of assets, liabilities, and contractual relationships. In addition to deciding the contract assignability issues above, Marion would also need to decide whether to separate Patriot's assets and cash flows from the potential claims of Marion's spirits creditors. That is, should the contracts and assets of the spirits business be placed in a single bundle together with the Patriot contracts, or should they be kept separate, perhaps in a bundle of their own?

The numerical example assumed that Marion set up a separate corporation called Patriot and that Patriot served as the common party to the supplier contracts. Under the default rules of law, this structure would provide for asset partitioning: Patriot's suppliers/creditors would have priority

of incomplete information about the value of these residual claims would likely render this solution ineffective as a means of providing liquidity to Marion.

48. According to lawyers who specialize in corporate mergers and acquisitions, the selling party in an asset sale will often obtain from the purchaser an agreement to hold the selling party harmless from any claims by counterparties to contracts that the seller has assigned to the purchaser. These agreements are presumably of relatively little value to the seller/assignor, however, when the purchaser/assignee is insolvent. But this is precisely the situation in which residual liability seems most likely to be invoked, since the counterparty would likely find it easier to simply pursue the purchaser/assignee directly if that party were solvent. E-mail from Paul Kingsley, Partner, Davis, Polk \& Wardwell, to Henry Hansmann and Marshall S. Huebner, Partner, Davis, Polk \& Wardwell (Mar. 2, 2012, 12:32 EST) (on file with authors); E-mail from Charles Nathan, Partner, Latham \& Watkins (Feb. 15, 2012; 11:41 EST) (on file with authors); Interview with Ruben Kraiem, Partner, Covington \& Burling (Oct. 23, 2009); Interview with Ruben Kraiem, Partner, Covington \& Burling (Feb. 18, 2011). 
over the spirits creditors with respect to the assets and cash flows generated by Patriot Beer. ${ }^{49}$ But Patriot's creditors would not have any claim to assets owned by the spirits business, since the parent corporation would have limited liability for the debts of its subsidiary.

If, by contrast, Patriot were held as an unincorporated division of Marion-that is, if Marion served as the signatory of both the Patriot Beer contracts and the spirits contracts - then there would be no asset partitioning. All creditors would share in the common pool of assets created by the spirits and beer divisions. If it were possible, might Marion consider making the Patriot Beer contracts bundled assignable, but not partitioned from the spirits division?

Extending the logic of our theory, it is unlikely that Marion would want to do this. More likely, business owners like Marion will prefer that a transferable bundle also be a partitioned bundle. Partitioning ensures that the bundle of assets and contracts bonding the suppliers/creditors' claims when a sale does not occur is the same as the bundle that bonds suppliers/creditors' claims when a sale does occur. Defining the two bundles differently can give rise to the same opportunistic transfer problems we encounter in our Patriot Beer example.

To see this, consider the possibility that Patriot Beer and the Marion spirits division are separable but not partitioned. In other words, suppose Marion could sell Patriot by freely assigning the Patriot bundle to a new owner. The sale would separate the Patriot bundle from the spirits bundle. Suppose this is possible without the consent of any contractual counterparties (and without residual liability, which is problematic for the reasons above),$^{50}$ but the contractual counterparties in each bundle have claims on the common pool of assets generated by the two businesses if they are not separated. This legal structure would give Marion an incentive to sell Patriot Beer even if it is inefficient to do so. The sale of Patriot would divert value from Patriot's contractual counterparties by exposing them to greater credit risk. The contractual counterparties to the beer business would have a smaller pool of assets to reach in case the business were to become insolvent after the sale. As with Patriot and its bottle supplier, the potential to divert value from contractual counterparties creates an incentive for opportunistic transfers by Marion. And this reduces Marion's incentive to invest in any complementarities that might exist between the spirits business and Patriot Beer.

As a result, if Marion values the option to sell Patriot at a later date, she will likely prefer to partition the assets and liabilities of the two firms at the outset. By ensuring that Patriot's counterparties have no claim to Marion's other assets whether or not Patriot is eventually sold, Marion eliminates her

49. See supra note 8 .

50. As before, if Marion values the ability to sell Patriot at a later date (for liquidity reasons or because the spirits division may have negative synergies with Patriot), Marion will likely prefer to avoid residual liability. Marion will not want to be exposed to a liability whose value would be determined by the actions of Patriot's new owner. 
capacity to make an opportunistic transfer, and hence enhances investment incentives.

\section{G. The Costs of Nonassignability}

We do not mean to imply that all contracts should be made nonassignable in all circumstances. Note that we have assumed, so far, that the inventory software investment made by Marion is valuable only when used in the current bundle. It is also possible that, after making an investment in an asset, Marion realizes that the asset has more value outside the current firm than inside. In the context of our Patriot Beer example, it may turn out that the bottle supply contract, after the investment in the inventory management software, has more value with MW (or some other brewer) than it has with Patriot. If this is the case, removal of Marion's option to assign freely can lead to a holdup problem: the supplier might extract value from Marion when the investment is worth more outside the bundle than inside, but Marion must seek the supplier's permission to assign his contract.

This suggests that there is a potential cost to making a contract individually nonassignable. More often than not, we would expect that Marion will choose a particular counterparty because-as with the bottle supplier - the inputs provided under the contract with that counterparty will be complementary with the current firm, and investments in that relationship will increase these complementarities. Nevertheless, there may be circumstances in which Marion and her counterparty will agree to make their contract assignable. When Marion's incentive to assign opportunistically is low (due to the absence of a credit-risk-transfer or nonverifiable quality problem) or when it is sufficiently likely that an investment in the relationship will be worth more outside the bundle than inside, free assignability can be preferred to nonassignability. ${ }^{51}$

\section{ACHIEVING BUNDLED AsSignabILITY WITH AND Without Legal ENTITIES}

Our economic theory shows that bundled assignability resolves the tension between an owner's need for liquidity and counterparties' demand for protection against opportunism, while giving owners efficient incentives to assemble contracts that are complementary in value and make investments that augment this complementarity.

51. Better still, the parties might try to make their contract conditionally assignable. That is, they could try to write the contract to allow for free assignability when the contract is worth more outside the firm than inside, but prevent it otherwise. If this were possible, Marion could be prevented from opportunistically assigning the contract, and the supplier could be prevented from holding up Marion's investments. We will revisit this issue in the context of assignability in bankruptcy, which is a form of conditional assignability. See infra Section VII.A. 
To understand how legal entities help establish bundled assignability, consider two familiar arrangements for using a business corporation to achieve bundled assignability.

First, and most simply, the owner can form a corporation of which she is the sole shareholder, and then have the corporation sign contracts with the firm's counterparties that are nonassignable. ${ }^{52}$ The owner will have liquidity, because she can sell her stock in the corporation for cash and the sale of stock will not be considered an assignment of the corporation's contracts. This will transfer the firm's contracts, as a bundle, to its new owner. Counterparties cannot prevent the stock sale, so they are unable to hold up the owner and extract any of the value of the owner's investments in assembling the contracts and augmenting their complementarity. At the same time, the owner could not opportunistically transfer one of the contracts apart from the rest without permission, because the parties are all tied to the same legal entity.

A second way to bundle contracts by means of an entity is to write assignment clauses that use the entity to define the bundle. These clauses are slightly more complicated but allow the owner to cash out by way of an asset sale instead of a stock sale. ${ }^{53}$ To do this, the owner sets up a corporation and takes ownership of its stock, as before. The corporation then signs contracts with its counterparties that bar individual assignment but permit assignment to a party that acquires all (or substantially all) of the contracts and assets of the corporation. If all of the counterparty contracts take this form, the owner would also have bundled assignability. ${ }^{54}$

Now consider how the owner might try to achieve the same benefits without using a separate legal entity. One way is for the owner to sign personal contracts that are nonassignable but that enumerate, in each contract, the other components of the bundle with which the counterparty wishes to be tied, allowing for assignment only if all the other contracts in the defined bundle are also assigned to the same person. For a business of any measurable complexity, however, this would be extremely costly and unreliable. To take one example, Boeing uses 700 different suppliers to create one of its airplanes. ${ }^{55}$ Attempting to identify and bundle each of the 700 supply contracts with the 699 other contracts would be messy, labor-intensive, and

52. Keep in mind that the owner may be an individual, a Fortune 100 parent company, or anything in between.

53. Allowing for a future asset sale, instead of a stock sale, might be useful for several reasons. First, tax liability for the buyer and the seller will differ in an asset sale and a stock sale. Second, the buyer might prefer to avoid any hidden liabilities that would attach to the assets in a stock sale but not in an asset sale.

54. A sale of all or substantially all of a corporation's assets to another corporation is generally treated as an assignment of its contracts, hence requiring consent by the counterparty of each individual contract that has not been made transferable by an explicit provision in the contract. See Elaine D. Ziff, The Effect of Corporate Acquisitions on the Target Company's License Rights, 57 Bus. LAw. 767 (2002).

55. Jim Destefani, A Look at Boeing's Outsourcing Strategy, ManUfacturing EnGINEERING, Mar. 2004, at 65, 67. 
potentially fraught with error and ambiguities in identification. Moreover, because suppliers change over time, each contract would need to anticipate these future contracts and identify them in some way before they came into existence. In short, this is unlikely to be a practical solution in most realistic cases.

Alternatively, bundled assignability might be achievable without an entity by way of a general description of the bundle. The owner might sign contracts in her own name that, by their terms, permit assignment if and only if the assignment is to a person who purchases, for example, "all or substantially all of the assets of the Patriot Beer business." This would not require a precise description in each contract of the other contracts that constitute the bundle. This solution might prove complicated, however, in the event that the owner wishes to separate Patriot from another business she owns or from her personal assets, and distinguishing the Patriot Beer assets is not easily verifiable (for example, because of shared facilities or overhead). The Patriot suppliers might argue, for example, that the definition of the bundle being sold is underinclusive. More particularly, they might use this ambiguity opportunistically to hold up the owner and extract more value from the sale. As we have seen, these opportunism problems can lead to underinvestment in the business.

This risk will be greater to the extent that the owner runs multiple businesses that use assets and contractual rights in common. Consider, again, Marion's spirits business. If the same distributor contract is used to distribute both Patriot Beer and Marion's spirits, would the distribution contract be treated as a Patriot Beer asset and be included in the sale? When key employees provide services to both firms, which employees will move with Patriot in the event of a sale? In comparison, a bundle that references the entity creates substantially less ambiguity. The owner need only show that an asset not being transferred is not owned by the entity being sold, or that a contract not being assigned has a different legal person as a signatory. This provides more certainty and assurance against an opportunistic holdup problem.

As another alternative, parties might try to eliminate the ambiguity problem by creating a central "node" that is common to all of the contracts that are to be included in the bundle. For example, Marion might create a Patriot Beer trademark, and specify in each contract that the contract can be assigned only to a purchaser of the trademark and only on the condition that all other contracts similarly tied to the trademark are also assigned to that purchaser. While this approach to bundled assignability seems feasible in principle, it also seems much clumsier than simply using a transferable entity in combination with the default rules of contract assignability. In addition to creating a central "node," transferable entities are necessary to create asset partitioning. ${ }^{56}$ That is, entities make it possible to identify a constantly changing bundle of assets and contracts to which the firm's suppliers and other creditors-who are themselves constantly changing-

56. Hansmann \& Kraakman, supra note 7, at 406-22. 
can attach in the event of a default. ${ }^{57}$ The entity separates these assets and contracts from the claims of the owners' personal creditors and the creditors of her other businesses. For the reasons listed above, asset partitioning is a natural complement to bundled assignability - the two should generally go together. And because asset partitioning is practically impossible without the use of a legal entity, it follows that a legal entity is a superior method of achieving bundled assignability.

\section{EMPIRICAL EvidenCE of BundLed Assignability}

Our theory explains why parties might prefer to structure their contracts to prevent individual assignability yet permit bundled assignability. We have also argued that legal entities play an important role in creating and identifying the bundle of assets and contracts that can be freely transferred. In this Part, we present preliminary evidence of this role from the assignment clauses of commercial contracts. We focus on two basic questions: First, do contracting parties actually contract for bundled assignability in practice? Second, do they use entities as a means of achieving bundled assignability? Our data answer both questions strongly in the affirmative. To our knowledge, this is the first empirical study of assignability in commercial contracts, or indeed in any type of contracts, to appear in the literature of either law or economics. ${ }^{58}$

We examine 287 supply and lease contracts from public firms, gathered from the Securities Exchange Commission ("SEC") Edgar database, between 2007 and 2009. We restrict consideration to supply contracts and leases. These contract types are likely to fit the underlying assumptions of our theory, since they are typically bilateral executory contracts with inputs that have the potential to become specific and complementary to the firm. For consistency and to focus on the credit-risk-transfer problem, we also restrict attention to the "debtor" side of the contract (the tenant or buyer). The results are available in Appendix B.

Table 1 presents the results on individual antiassignment clauses. The data show that contracting parties routinely contract out of individual assignability: the "debtor" side of the contract is explicitly prevented from individually assigning its contractual rights and obligations in $95.5 \%$ of the contracts in our sample. The percentage of leases that are nonassignable by

57. Id. at 417-22 (observing that a legal entity goes beyond ordinary security interests by providing, in essence, for creation of a lien that not only floats over a constantly changing pool of assets-namely all assets owned by the firm-but also floats under a constantly changing pool of creditors-namely all persons to whom the firm has contractual or extracontractual obligations).

58. Systematic study of contract terms through the examination of large pools of comparable contracts is a recent phenomenon, importantly aided by the SEC Edgar database that we use here. The Edgar database includes copies of all materially important contracts entered into by companies registered under the federal securities laws. The pioneering work in this area was done by Eisenberg and Miller. See, e.g., Theodore Eisenberg \& Geoffrey P. Miller, The Flight from Arbitration: An Empirical Study of Ex Ante Arbitration Clauses in the Contracts of Publicly Held Companies, 56 DePaul L. Rev. 335 (2007). 
the tenant is even higher than the percentage of supply contracts that are nonassignable by the buyer ( $99.2 \%$ vs. $91.7 \%$ respectively). This may be true because leases, having a larger pool of potential users, are more subject to an opportunistic transfer problem than is a supply contract.

Table 2 reports summary statistics on bundled assignability. We define a contract as "bundled assignable" if the contract explicitly restricts individual assignability yet permits free assignment (under some conditions) if the contract is assigned along with some other asset(s) or contract(s) in the firm. We create two definitions of bundled assignability. In the first, the contract is coded as explicitly bundled assignable if the contract is individually nonassignable and explicitly permits assignment with a designated bundle. ${ }^{59}$ In the second, the contract is coded as implicitly bundled assignable if the contract is individually nonassignable but does not explicitly restrict assignability in the event of a merger, acquisition, or change in control. As we have discussed, this generally creates bundled assignability under the default rules of law, since mergers and acquisitions are not held to be violations of individual antiassignment clauses. We find that bundled assignability is very common in our sample: 85.7 percent of the contracts in the sample create some form of bundled assignability for the debtor party to the contract. Over 63 percent of contracts create this bundled assignability explicitly by identifying bundles with which the contract can be assigned. An example of an explicit bundled assignability clause from our sample is available in Appendix $\mathrm{C}$.

In Table 3, we report summary statistics for those contracts that explicitly permit bundled assignability, to see whether contracting parties use entities or some other means to define the bundles with which the contract may be assigned. If the contract permits assignment in the event of a merger,

59. Interestingly, it appears that residual liability often is not waived when one corporation acquires another in its entirety through an asset sale. Our empirical study reveals no instances of contract terms relieving a party from residual liability when a contract is assigned, even when the contract explicitly permits bundled assignment via an asset sale. And conversations with practitioners indicate that relief from residual liability, though commonly sought by the seller, is frequently not obtained via novation at the time a firm's assets are sold: counterparties have little incentive to consent, and the more strongly the seller insists on obtaining novations, the more suspicious the counterparties become of the transaction and the less inclined they are to agree.

In any event, it seems clear that contractual counterparties in general do not consider residual liability to be adequate protection against opportunistic assignment. Perhaps the strongest evidence of this is that nearly all of the contracts in our empirical study explicitly bar individual assignability (which provides residual liability under the default rules of law). Residual liability may serve as an adjunct to bundled assignability in protecting counterparties in the relatively rare event of an asset sale. But there is reason to believe that, even here, the added protection is modest. As discussed above, there are a variety of strategies by which the selling corporation can make it expensive or impossible to collect on a claim of residual liability. Most tellingly, the seller usually has the choice of an asset sale or a stock sale (which provides no residual liability) in the bundled assignability clauses we observe in our data. It is unlikely that counterparties actively rely on residual liability as protection in the broad run of cases, given that the seller typically has the option to deny it via stock sale (and usually exercises that option). 
acquisition, or sale of "all or substantially all assets" of the contracting entity, then an entity is being used to define the bundle. Alternatively, if the contract allows for assignment along with a specifically identified asset or contract, or if the contract provides a general description of a bundle ("the business/segment to which this agreement relates"), we consider the bundle definition to be non-entity-based. Some contracts use multiple definitions of the bundle with which the contract can travel; we record all definitions used by the parties in a given contract.

Of the contracts that create bundled assignability explicitly, $93.9 \%$ include an entity-based definition of a bundle, and $63.5 \%$ use only an entity-based definition. Nevertheless, we do find evidence that bundles are sometimes defined in a way that would not require entities: $36.5 \%$ of the bundled assignable contracts in our sample include at least one definition of a bundle that does not use an entity, and $6.1 \%$ of these contracts use only non-entity-based definitions of bundles. ${ }^{60}$

These simple summary statistics provide evidence that contracting parties are aware of the economic forces underlying our theory. In practice, parties contract explicitly for bundled assignability with great regularity. When parties create bundled assignability, they usually, though not exclusively, use entities to define the bundle with which the contract can travel. This suggests that legal entities are a valuable, though not indispensable, device for balancing the owner's need for liquidity against counterparties' demand for protection against opportunism.

\section{FURTHER IMPLICATIONS}

Our theory also provides perspective on more specific legal issues involving the relationship between contract assignability and legal entities. We focus here on the two principal exceptions to general legal doctrine concerning individual and bundled assignability. The first involves a class of transactions, namely bankruptcy, while the second involves a class of contracts, namely licenses for intellectual property.

\section{A. Bankruptcy Law and Individual Assignability}

In our numerical example, the reason why counterparties wish to restrict the firm's ability to assign their contracts essentially lies in credit risk. And it is the collection of other contracts to which the firm is a party that keeps its credit risk low. This is only one of various reasons why a firm's counterparties may be concerned about the other contracts in the bundle held by the firm. It is perhaps the most important reason, however, and it seems to help

60. This is not to say that entities would not be useful ex post, even if the bundle is defined without explicitly referencing an entity in the contract ex ante. It would be much harder for a supplier to argue that the firm did not transfer "the business to which this agreement relates" if the firm sold the entire capital stock of the entity in which the business's assets and contracts were contained. Thus, our statistics are a conservative measure of the extent to which entities are valuable in creating bundled assignability. 
explain the law's presumptions as to whether various corporate transactions constitute assignments of the firm's contracts.

For example, most contracts that are otherwise individually nonassignable by virtue of their explicit terms are held to be individually assignable in bankruptcy. ${ }^{61}$ The standard argument for this override of contractual terms is that it helps the bankrupt debtor. By assigning an otherwise nonassignable contract, the debtor can capture the value of a profitable contract it does not intend to use, and this can enhance the firm's reorganization prospects. ${ }^{62}$ This argument proves too much, however, since there are an infinite number of ways in which bankruptcy law could weaken a counterparty's substantive rights to favor the debtor. Why does bankruptcy law select this alteration of rights in particular?

Our theory provides a reason why the law leans in favor of individual assignability for debtors in bankruptcy. ${ }^{63}$ In our numerical example, the value destroyed by opportunistic assignment arises when investments create complementarity between contracts-that is, when the firm's contracts are worth more together than separated. This value-destroying assignment threat is particularly severe when the assigning firm is more creditworthy than the potential assignee, because the payoff that might be received from the assignee is greater when the difference in creditworthiness between the assignor and the assignee is greater. At the same time, free assignability of contracts might sometimes be valuable and create the best possible incentives for investment. This is most likely to be true when investments have more value outside the bundle than inside.

Bankruptcy is a particular state of the world in which individual assignment of contracts is often more efficient than opportunistic. Firms in bankruptcy are more likely than firms in the general population to be worth more broken up than kept intact (i.e., the firm in bankruptcy is less likely to have positive "going-concern value"). Furthermore, it is safe to assume that firms in bankruptcy, which are typically insolvent, will be less creditworthy than any potential assignee. The chance that a supplier to a firm in bankruptcy will suffer an increase in credit risk from being assigned to another firm is much less than would be the case if the potential assignor were financially healthy.

In this sense, bankruptcy might be considered a way of achieving conditional assignability: in states of the world that are more likely to involve assignment of the value-destroying, opportunistic kind, the antiassignment provisions normally included in contracts are respected. In bankruptcy states, where opportunism is reduced and assignment is more likely to be efficient, the law overrides contractual terms to prevent the firm's counter-

61. 11 U.S.C. $\S 365(\mathrm{f})(2006)$.

62. See, e.g., Charles Jordan Tabb, The Law of Bankruptcy 865 (2d ed. 2009).

63. The Bankruptcy Code also leans in favor of assignability by relieving the estate from residual liability after a permitted assignment. 11 U.S.C. $\$ 365(\mathrm{k})$. 
parties from holding up an efficient assignment. ${ }^{64}$ Moreover, the opportunism problem is limited by the bankruptcy judge, who is charged with permitting assignments only if there is "adequate assurance of future performance." 65

\section{B. Licenses for Intellectual Property}

Licenses for intellectual property constitute the most important class of contracts that are treated as exceptions to general legal doctrines concerning both individual and bundled assignability. We focus here on the two most important of these exceptions: the exception to individual assignability in bankruptcy and the exception to bundled assignability in mergers.

Intellectual property licenses are clearly subject to the credit-risk-transfer problem that is the principal focus of our analysis. Indeed, intellectual property licenses may be the most valuable contractual rights that the licensee holds-they can give great value to, and gain great value from, other contracts in the bundle if the bundle is well chosen. Because, as we have argued immediately above, the credit-risk-transfer problem is mitigated in bankruptcy, one might expect intellectual property licenses, like other contracts, to be individually assignable in bankruptcy even if they contain an explicit anti-assignment provision. But that is not the case. Contracts that are nonassignable under the default rules of law outside of bankruptcy, such as nonexclusive ${ }^{66}$ intellectual property licenses, also cannot be individually assigned by the firm when it is in bankruptcy. ${ }^{67}$

Intellectual property licenses are also important exceptions to the normal rules that favor bundled assignability in corporate mergers and acquisitions. The general rule is that the merger of two corporations is not considered an assignment of the contracts of either corporation. Rather, the successor corporation resulting from a merger simply assumes the rights and obligations of all contracts previously held by each of the two merging companies just

64. We are not attempting here to rationalize the entirety of bankruptcy's treatment of executory contracts. More specifically, our theory does not explain why the Bankruptcy Code makes this contingent assignability in bankruptcy states a mandatory rule, as opposed to a default rule that parties could contract around by explicitly restricting assignment inside bankruptcy. While opportunistic assignment due to a credit-risk-transfer problem is substantially less likely in bankruptcy, opportunistic assignment due to a nonverifiable quality problem may not be. Thus, there may be good reasons to give contracting parties space to preserve nonassignability inside bankruptcy as well as outside.

65. 11 U.S.C. $\$ 365(f)(2)$ (B).

66. The class of contracts that is given exceptional treatment is generally comprised of nonexclusive licenses for intellectual property - that is, licenses to exploit a patent, copyright, or trademark that continue to permit the licensor, or other licensees, to exploit the right as well. A typical example might be a license in which a patent holder grants to a manufacturer the right to use a patented production process in making the manufacturer's products, while reserving and exercising the power to license other manufacturers to use the same process. An exclusive license, in contrast, gives a single licensee the sole right to exploit the intellectual property right in question.

67. See Neil S. Hirshman et al., Is Silence Really Golden? Assumption and Assignment of Intellectual Property Licenses in Bankruptcy, 3 HASTINGS Bus. L.J. 197, 212-15 (2007). 
as if there were full continuity of corporate personality. ${ }^{68}$ If we focus on the credit-risk-transfer problem, this rule makes good sense. In a merger, a contract is not separated from the other contracts with which it was initially bundled. Rather, that initial bundle simply becomes part of a larger bundle. The result is that a merger typically decreases rather than increases the credit risk faced by the counterparties to contracts with the merging corporations.

But here, some courts have created an exception to the general rule of bundled assignability, holding that, in the case of a nonexclusive license for intellectual property, a merger is to be considered an assignment. ${ }^{69}$ The result is that, absent specific consent, a license that is not individually assignable will not pass to a corporation that results from a merger. The courts are not unanimous on the issue, however, and the doctrine remains ill defined and controversial. Indeed, intellectual property licenses are the almost exclusive focus of recent literature dealing with the effect of corporate mergers and acquisitions on contract assignability. ${ }^{70}$

A plausible justification for the more restrictive approach to nonexclusive intellectual property licenses in both bankruptcy and mergers is that, by their nature, such licenses can provide special occasion and incentive for

68. See Note, supra note 19 , at 394 .

69. The most prominent of these cases has been PPG Industries, Inc. v. Guardian Industries Corp., 597 F.2d 1090, 1096-97 (6th Cir. 1979) (finding that a merger is an improper "transfer" of a patent license, even in the absence of an express nonassignment clause). This approach was pressed a bit further in SQL Solutions, Inc. v. Oracle Corp., No. C-91-1079 MHP, 1991 WL 626458, at *6 (N.D. Cal. Dec. 18, 1991) (finding an improper assignment as a consequence of a reverse triangular merger, a form of merger that is similar to a simple sale of stock). See also In re Alltech Plastics, Inc., 5 U.S.P.Q.2d (BNA) 1806 (Bankr. W.D. Tenn. Dec. 30,1987 ) (finding that a sale of stock constitutes an assignment, though in a bankruptcy context). Some decisions-PPG, F.2d at 1095 , is an example-have additionally held that a nonassignability term will be implied by law in contracts where there is no such express term, putting the burden on the parties to a license to make the license explicitly transferable if that is what they wish. For an extensive and thoughtful review of the case law, see Ziff, supra note 54 , at $771-75$.

70. See, e.g., Aaron Xavier Fellmeth, Control Without Interest: State Law of Assignment, Federal Preemption, and the Intellectual Property License, 6 VA. J.L. \& TECH. 8 (2001); Hirshman, supra note 67; Madlyn Gleich Primoff \& Erica G. Weinberger, E-Commerce and Dot-Com Bankruptcies: Assumption, Assignment and Rejection of Executory Contracts Including Intellectual Property Agreements, and Related Issues Under Sections 365(c), 365(e) and 365(n) of the Bankruptcy Code, 8 AM. BANKR. INST. L. REv. 307 (2000); Ziff, supra note 54; Jessica L. Braeger, Note, Antiassignment Clauses, Mergers, and the Myth About Federal Preemption of Application of State Contract Law to Patent License Agreements, 50 DRAKE L. REv. 639 (2002); Joshua G. Graubart, Unintended Consequences: State Merger Statutes and Nonassignable Licenses, 2003 Duke L. \& Tech. Rev. 25; Philip M. Haines, Comment, The Efficient Merger: When and Why Courts Interpret Business Transactions to Trigger AntiAssignment and Anti-Transfer Provisions, 61 BAYLOR L. REv. 683 (2009); Shannon D. Kung, Comment, The Reverse Triangular Merger Loophole and Enforcing Anti-Assignment Clauses, 103 Nw. U. L. Rev. 1037 (2009); Peter Macaulay, Note, The Effect of Mergers on AntiAssignment Provisions in Contracts: A Case Note on TXO Production Co. v. M.D. Mark, 53 Baylor L. Rev. 489 (2001); H. Justin Pace, Note, Anti-Assignment Provisions, Copyright Licenses, and Intra-Group Mergers: The Effect of Cincom v. Novelis, 9 Nw. J. TECH. \& INTELL. PROP. 263 (2010). 
two types of opportunistic assignments other than the credit-risk-transfer problem on which we've focused. The first and most obvious is the assignment of the license to another enterprise that is a direct competitor of the licensor or of other licensees. The second is the assignment of the license to another firm that is much larger than the original licensee, leading to a far more extensive exploitation of the license than the licensor contemplated in the original contract.

In contrast to the credit-risk-transfer problem, neither of these additional forms of opportunistic individual assignment is less threatening when a firm is in bankruptcy than when it is not. On the contrary, such opportunism visà-vis the licensor may be the most rewarding course for the bankrupt firm and its other creditors. And, in contrast to its tendency to mitigate the creditrisk-transfer problem, a merger can in fact be a convenient instrument by which to accomplish the opportunistic transfer of a license to a competitor or to a much larger licensee. These special reasons for barring assignment of nonexclusive intellectual property licenses have, in fact, been invoked by both the case law ${ }^{71}$ and the legal literature to justify the unusual treatment given to intellectual property licenses in bankruptcy law and merger law.

In fact, the problems of assignability presented by nonexclusive intellectual property licenses in mergers can well be seen as a special manifestation of the nonverifiable quality problem ${ }^{72}$ - one in which bundling is less likely to provide protection against opportunistic transfers. The essence of the nonverifiable quality problem we described above is that a contract will be opportunistically assigned to a person who, though posing no increase in credit risk, would impose costs on the original counterparty in other ways. The assignment might associate the original counterparty with a low-quality enterprise and damage its reputation in general, or it might make it more costly for the counterparty to perform its part of the bargain. If the relevant differences in quality are driven primarily by the character of the firm's other contractual inputs, a counterparty can sufficiently protect herself by insisting that her contract continue to be exploited together with the other contracts in the original bundle.

But in the intellectual property case, simply remaining bundled with the firm's other inputs may provide little protection against opportunistic use of a license. The opportunism derives, instead, from the character of the acquirer's existing business to which the license has been added. To put the issue differently, a licensor may primarily wish to avoid being added to a different bundle, whether or not the bundle to which the license is currently tied moves together with the license.

None of this is to say that our theory demonstrates that the special rules regarding assignment of intellectual property make good law. We have

71. See, e.g., $P P G, 597$ F.2d at 1096-97 (finding an invalid assignment where successor firm was a competitor of licensor); Nat'l Bank of Canada v. Interbank Card Ass'n, 507 F. Supp. 1113, 1124 (S.D.N.Y. 1980), aff'd, 666 F.2d 6 (2d Cir. 1981) (finding an invalid assignment because successor firm considerably larger than the original licensee).

72. See supra text accompanying notes $25-26$. 
shown only why licensors of intellectual property might often have reason to be more conservative about permitting assignment than other contractual counterparties. It does not necessarily follow that the default rules of law regarding assignment should be different for intellectual property licenses than for other types of contracts, either in the context of bankruptcy or in the context of mergers. The alternative in the case of bankruptcy is to depend on the discretion of the bankruptcy courts to bar assignment of a license only when the nature of the proposed assignee's business would make the assignment especially burdensome to the licensor. And the alternative in the case of mergers is to leave it to licensors to insist on a change-of-control clause-perhaps a tailored one that prohibits mergers with large licensees or competitors of the licensor - in any license that they fear might be transferred opportunistically via merger. The choice of a default rule in these cases, as elsewhere, involves trade-offs. Our object here is limited to clarifying some of the costs and benefits that need to be weighed in the balance. ${ }^{73}$

\section{CONCLUSION}

The modern firm's value is increasingly embedded in its contractual rights. At the same time, modern firms are increasingly organized as clusters of subsidiary entities under the common ownership and control of a corporate parent. This Article creates a new link between the importance of contracts and the widespread use of subsidiaries that has not previously been emphasized.

We have argued that subsidiary entities are useful tools in facilitating the transferability of a business segment whose value depends importantly on its contracts. Our theory emphasizes that bilateral contracts create risks of opportunism by the firm and its counterparties when transferability is at issue. Owners value the ability to sell their business segments, but counterparties have incentives to hold up a sale and extract value from the owner when their consent is required. Owners, by contrast, have incentives to seek out low-quality assignees if counterparties gave an overly broad permission to assign their contracts individually.

We show that the two-sided risk of opportunism can be mitigated through "bundled assignability" - the owner of a business segment is free to transfer the segment's contracts and assets to a new owner, but only if they are transferred together. When the quality of a firm's performance depends on its other inputs, bundling provides appropriate assurance to a counterparty that she will receive the effective performance she was promised, whether or not the segment is sold. And it assures owners that they can get the liquid-

73. It is certainly plausible that the objections to transferring intellectual property licenses have become excessively salient relative to the virtues of (bundled) assignability. As one thoughtful commentator says, in reviewing the case law, "[T] he negative effect on the licensee caused by the non-transferability of its rights has, surprisingly, not appeared to be as significant as the licensor's interest in controlling the identity of its licensees or is overcome by other factors." Ziff, supra note 54, at 768 . The analysis of the benefits of bundled assignability that we offer here, we hope, may help correct this imbalance. 
ity they need without risk of holdup. Mitigating these opportunism problems is important, we show, because it encourages owners to make investments that add value to the bundle.

Placing a business in a subsidiary entity provides a convenient and reliable way to create bundled assignability. While other methods of creating bundled assignability are also possible, these alternatives have important flaws that weigh in favor of using a separate entity, particularly when transferability is important to the owner. Our analysis of assignment terms in commercial contracts confirms that contracting parties recognize the benefits of using entities for this purpose. An appreciation of this role of legal entities not only refines our legal and economic theories of the firm but also provides guidance in understanding both legal doctrine and contracting practices regarding assignability. 


\section{APPEndix A: RoBustness Checks}

\section{Bundling Contracts to Assets}

Suppose that all numerical values are the same as in the numerical example in the main text, except that Marion begins the game at Date 1 with ownership of the other four inputs, free and clear of any liabilities. She must contract for the bottles, using the bottle supplier as a creditor, as above.

First, suppose the bottle supply contract is individually assignable, and suppose the bottle supplier will continue to demand $10 / 0.5=20$, as before. If the owner invests, but chooses not to assign, the value of her equity in the firm is $1 \cdot(100-1 \cdot 20)-2=78$. If she invests and chooses to assign, the owner will receive $0.95 \cdot(100-1 \cdot(10 / 0.95))-2=83$. Since assignment is preferred to nonassignment conditional on investing, the contract prices set by suppliers are consistent with equilibrium behavior by the owner. It can also be shown that a contract price of 10 will not constitute an equilibrium, since the owner will prefer assignment. Since the owner prefers assignment after investing, it is clear that the owner will never invest, for the same reasons as above. The owner then will not invest but rather will assign. Her equity value will be $.95 \cdot(100-1 \cdot(10 / 0.95))=85$.

Next, suppose the bottle supply contract is bundled with the other four inputs. Suppose the bottle supplier will be willing to agree to a contract price of 10. The owner's payoff if she does not invest is $0.95 \cdot(100-$ $1 \cdot(10))=85.5$. If the owner invests, her payoff, net of the investment cost, is $1 \cdot(100-1 \cdot 10)-2=88$. The owner prefers to invest under bundling. Thus, the contract prices set by the suppliers are consistent with equilibrium behavior by the owner. Since the owner's equity is worth 88 under bundling and 85 under individual assignability, the owner will prefer bundling at Date 1.

\section{Other Sources of Complementarity}

Suppose that all numerical values are the same as before, but investment is not required to generate complementarities: if the original five inputs are kept together, Patriot will succeed with certainty, otherwise it will succeed with probability 0.95 . It is clear that the Date 3 decision problem for the owner is the same as the decision problem above after the owner has invested. Suppose the suppliers will set their contract prices as above: the bottle supplier will require a contract price of 20 and the other suppliers will demand $10 / 0.95$. If the owner chooses not to assign, she will receive $1 \cdot(100-$ $4 \cdot(10 / 0.95)-1 \cdot 20)=38$. If the owner chooses to assign, the owner will receive $0.95 \cdot(100-5 \cdot(10 / 0.95))=45$. The owner prefers to assign, since $45>38$. Thus, under individual assignability, the contract prices set by suppliers are consistent with equilibrium play by the owner. It can also be shown that it is not an equilibrium for suppliers to set contract prices of 10 , since the owner will prefer to assign the bottle supplier at Date 3 (MW will 
pay the owner a price of 5). Given that she prefers to assign at Date 3, the value of the owner's equity is 45 at Date 1 .

Now suppose the owner bundles the five contracts together. Suppose, as above, the suppliers agree to contract prices of 10 . Given this, her equity value is $1 \cdot(100-5 \cdot 10)=50$. Since contracts cannot be assigned, contract prices of 10 are consistent with equilibrium. Since her equity value under bundling is $50>45$, the owner prefers bundling to individual assignability.

\section{Other Sources of Inefficient Assignment}

Another reason the owner might prefer nonassignability, in addition to reasons that involve complementarity between inputs, is to commit herself not to waste resources finding a potential assignee. Suppose, in contrast to the examples above, that the current bottle supplier is no more valuable than a replacement bottle supplier. Suppose that Patriot will succeed with probability 0.95 , and MW will succeed with probability 0.5 , irrespective of the identity of the bottling company or any investment made by the owner. This means that there are no complementarities between the bottling company and Patriot's other inputs. Suppose, however, that the owner, at Date 2, has the ability to search for an assignee like MW. The search costs 3 to Marion in direct costs and forgone opportunities. If the owner does not search, then she has no potential assignees.

Suppose first that contracts are assignable, and suppose that contract prices under assignable contracts are the same as above. If the owner searches and then assigns at Date 3, her payoff, net of the search cost, will be $0.95 \cdot(100-5 \cdot(10 / 0.95))-3=42$. If the owner does not search, and thus does not assign, her payoff is $0.95 \cdot(100-4 \cdot(10 / 0.95)-1 \cdot 20)=38$. Clearly the owner prefers to search and to assign, and her equity value net of search costs is 42 . If, by contrast, the owner bundles the contracts, her payoff is $0.95 \cdot(100-5 \cdot(10 / .95))=45$. Note that the owner's net payoff to bundling is $45-42=3$, which is equal to the cost of the search. In other words, the search cost is socially inefficient, and these social losses are ultimately borne entirely by the owner. By bundling the contracts together, she commits to preventing this loss of value.

\section{Renegotiation in the Shadow of Assignment}

In this example, we allow the bottle supplier and the owner to renegotiate to an outcome that prevents assignment when assignment destroys value. The simplest case to illustrate is one in which the supplier has all the bargaining power in renegotiation with the owner, so we will show the main result for this special case. In general, the qualitative result that individual assignability weakens incentives to invest in complementarities is true as long as the supplier has at least some bargaining power in renegotiation.

First, suppose that contracts are assignable, and suppose that contract prices under assignable contracts are the same as above. If the owner invests, but chooses not to assign, she will receive $1 \cdot(100-4 \cdot(10 / 0.95)-$ 
$1 \cdot(10 / 0.5))-2=38$. If the owner invests and chooses to assign, the bottle supplier will renegotiate to prevent the assignment. But recall that we assume the supplier to have all the bargaining power. Thus, the owner's outcome in bargaining is the same as if she in fact assigned. Thus, the owner will receive $0.95 \cdot(100-5 \cdot(10 / 0.95))-2=43$, her assignment payoff. As a result, if the owner invests, she prefers to assign the supply contract rather than keep it.

Now suppose the owner chooses not to make the investment. Her payoff if she does not invest and does not assign is $0.95 \cdot(100-4 \cdot 10 / 0.95-$ $1 \cdot(10 / 0.5))=36$. If she does not invest but does assign, she receives $0.95 \cdot(100-5 \cdot 10 / 0.95)=45$. Note that if the owner does not invest, there is no positive surplus to be had from renegotiation, since the bottle supplier is not complementary with Patriot. Thus, we can assume that the assignment actually takes place. Since 45 is the highest possible payoff for the owner of the four possible choices when contracts are assignable, she will choose not to invest but instead to assign. Given these preferences, the contract prices chosen by the suppliers are consistent with equilibrium behavior by the owner.

Under bundling, as before, the owner's payoff is $1 \cdot(100-5 \cdot 10)-2=$ 48 . Since $48>45$, she prefers bundling to individual assignability.

\section{APPENDIX B: TABLES}

The following Tables are based upon the authors' sample of 287 lease and supply agreements from the SEC Edgar database filed as "Material Contracts" (Exhibit 10) between 2007 and 2009. The debtor party is the buyer in a supply contract and the tenant in a lease contract.

TABLE 1

EXPlicit Individual Nonassignability, DebToR PaRTY

\begin{tabular}{|c|c|c|c|}
\hline Contract Type & Contracts (N) & $\begin{array}{l}\text { Individually } \\
\text { Nonassignable } \\
\text { Contracts (N) }\end{array}$ & $\begin{array}{c}\text { Individually Nonassignable } \\
\text { Contracts }(\%)\end{array}$ \\
\hline Supply & 145 & 133 & $91.7 \%$ \\
\hline Lease & 142 & 141 & $99.3 \%$ \\
\hline Total & 287 & 274 & $95.5 \%$ \\
\hline
\end{tabular}

Table 1 reports the contracts that explicitly impose restrictions on assignment of the contract on an individual basis. 
TABLE 2

Bundled Assignability, Debtor Party

\begin{tabular}{cccc}
\hline & & $\begin{array}{c}\text { Explicit Bundled- } \\
\text { Assignable } \\
\text { Contracts (\%) }\end{array}$ & $\begin{array}{c}\text { Explicit or Implicit Bundled- } \\
\text { Assignable Contracts (\%) }\end{array}$ \\
\hline Supply & 145 & $63.4 \%$ & $89.0 \%$ \\
\hline Lease & 142 & $62.7 \%$ & $82.4 \%$ \\
\hline Total & 287 & $63.1 \%$ & $85.7 \%$ \\
\hline
\end{tabular}

Table 2 reports the percentage of contracts that allow for bundled assignability by the debtor party to the contract. A contract is coded as explicitly bundled assignable if the contract both (a) is explicitly individually nonassignable (using the same criteria as in Table 1) and (b) explicitly permits assignment of the contract (possibly under specified conditions) if assigned to a party acquiring all or some specified subset of the assets or contracts of the debtor party. A contract is coded as implicitly bundled assignable if both (a) is individually nonassignable and (b) does not explicitly restrict assignment of the contract in the event of a merger, acquisition, or change in control of the debtor party. The sample is described in Table 1.

TABLE 3

Entity and Nonentity Bundle Definitions, Debtor Party

\begin{tabular}{ccccc}
\hline Contract Type & Contracts (N) & $\begin{array}{c}\text { Entity Bundles } \\
\text { Only (\%) }\end{array}$ & $\begin{array}{c}\text { Entity and } \\
\text { Nonentity } \\
\text { Bundles (\%) }\end{array}$ & $\begin{array}{c}\text { Nonentity } \\
\text { Bundles } \\
\text { Only (\%) }\end{array}$ \\
\hline Supply & 92 & $37.0 \%$ & $52.1 \%$ & $10.9 \%$ \\
\hline Lease & 89 & $91.0 \%$ & $7.9 \%$ & $1.1 \%$ \\
\hline Total & 181 & $63.5 \%$ & $30.4 \%$ & $6.1 \%$ \\
\hline
\end{tabular}


Table 3 reports percentages of explicitly bundled-assignable contracts that use entity-based and nonentity-based definitions of bundles with which the contract may be assigned. The sample includes only those contracts that are coded as explicitly bundled assignable, as reported in Table 2. A bundle is defined as an entity bundle if assignment is permitted in the event of a merger, acquisition, or a sale of all or substantially all of the assets of the debtor party to the contract. A bundle is defined as a nonentity bundle if assignment is permitted with (a) specific asset(s) and/or contract(s), or (b) a general definition of a bundle that does not specifically reference the debtor entity, such as "business" or "segment."

\section{APPENDIX C: \\ Example of Explicit Bundled-Assignability Clause}

The following assignment clause is taken from a supply contract between Ascent Solar Technologies, Inc. and TurtleEnergy, LLC regarding the supply of solar panels by Ascent Solar to TurtleEnergy: $:^{74}$

\section{Assignment}

17.1 Except as provided herein, no party shall assign this Agreement without the prior written consent of the other party hereto, and any purported assignment without such consent shall be deemed null and void.

17.2 Notwithstanding the foregoing, both parties shall be permitted to assign this Agreement in connection with a merger or sale of all or substantially all of their assets.

17.3 Buyer may assign a Purchase Order under this Agreement in favor of a third party before acceptance of the Purchase Order by Ascent subject to Ascent's prior written consent and payment by Buyer or the assignee of the price of the PV Modules before shipping.

74. Ascent Solar Techs. Inc., Photovoltaic Module Supply Agreement (Ex. 10.1) (Sept. 23, 2009). 